\title{
ED
}

THE WILLIAM DAVIDSON INSTITUTE AT THE UNIVERSITY OF MICHIGAN BUSINESS SCHOOL

\section{Returns to Schooling in Russia and Ukraine: A Semiparametric Approach to Cross-Country Comparative Analysis}

By: Klara Sabirianova Peter and Yuriy Gorodnichenko

William Davidson Institute Working Paper Number 719

September 2004 


\title{
Returns to Schooling in Russia and Ukraine: A Semiparametric Approach to Cross-Country Comparative Analysis*
}

\author{
Yuriy Gorodnichenko \\ University of Michigan \\ (ygorodni@umich.edu)
}

\author{
Klara Sabirianova Peter \\ University of Michigan \\ IZA, Bonn \\ (klaras@umich.edu)
}

September 2004

\begin{abstract}
This study provides the first set of estimates of the returns to schooling over an extended period in Russia and Ukraine (1985-2002). There has been an increase in returns to schooling in both countries but the increase is much bigger in Russia than in Ukraine. The intriguing question is why returns to schooling in Russia and Ukraine diverged so much over the transition period while the skill composition of employment did not. Our approach in analyzing the sources of cross-country differences in returns to schooling is to compare the Mincerian earnings functions between the two countries and then to employ decomposition techniques. Using semiparametric methods, we construct counterfactual wage distributions for university and secondary school graduates for Ukraine using the distributions of Russian characteristics, returns to characteristics, and unobservables. This allows us to decompose differences in returns to schooling between the two countries due to differences in the labor market returns (price effect), differences in unobservables (residual effect), and differences in the labor force composition (composition effect). We conclude that of these three effects the price effect makes a major contribution to the observed differences in the returns to schooling.
\end{abstract}

Keywords: returns to schooling, earnings function, semiparametric approach, decomposition, counterfactual, cross-country analysis, retrospective data, transition, Russia, Ukraine

JEL classification: C14, I20, J31, O15, O57, P50

*We are thankful to Belton Fleisher and an anonymous referee for useful comments. 


\section{Introduction}

This paper contributes to the understanding of the variation in returns to schooling among the countries that have gone through significant economic transformation. Although the general trend in returns to schooling has been increasing in the economies that moved from plan to market, we do observe significant variation in the speed of changes: e.g., Russia experienced a sharp increase in returns to schooling within a few years of reform, whereas Ukraine exhibited a very low rate of growth. The puzzling question is why returns to schooling in Russia and Ukraine diverged so much over the transition period while the skill composition of employment did not? This paper explores the sources of the differences in returns to schooling between Russia and Ukraine.

Our study takes advantage of the institutional comparability between the two countries. Russia and Ukraine were part of the Soviet Union until 1991. ${ }^{1}$ They shared the same government, institutions, and policies. As we demonstrate in the paper, the two countries had remarkably similar wage distributions, earnings structure, educational attainment, labor force composition, and returns to schooling during the pre-reform period. Even now Russia and Ukraine continue to have similar educational systems and workforce characteristics.

Despite this common history and similar initial conditions, the two economies performed rather differently. Ukraine made very few structural reforms until 1997 and only after 1997 did the speed of reforms accelerate and the scope widen (Linn, 2001). ${ }^{2}$ In assessing the progress of the transition to a market economy in all 27 countries of the region, the European Bank for Reconstruction and Development consistently scored the results of market reforms less favorably in Ukraine than in Russia (EBRD, 2001). The labor market outcomes of reforms in the two countries also turned out to be different. ${ }^{3}$ In Russia, overall wage inequality increased sharply, with a significant and notable increase in returns to schooling (Brainerd, 1998; Sabirianova,

\footnotetext{
${ }^{1}$ The breakup of Czechoslovakia is another interesting case for analyzing the divergence in returns to schooling between Czech and Slovak Republics during the reform period (see Chase, 1998; Filer et al., 1999).

${ }^{2}$ Typically, Russian economic reforms have preceded similar reforms in Ukraine. For example, Russia liberalized most domestic prices in January 1992, while Ukraine did so at the end of 1994. Ukraine introduced a uniform exchange rate two years later than Russia did, with a full current account convertibility introduced in 1997. Russia essentially completed mass privatization by July 1994, while Ukraine began its large-scale privatization program at the end 1994 (EBRD, 2001).

${ }^{3}$ Ukraine lagged behind Russia in labor market reforms. For example, Russia abolished the wage grid in the nonpublic sector in 1991, but Ukraine continued to allocate wages according the old wage grid based on the national agreement between trade unions and the government until 1993. Similarly, Russia abolished a system of penalties on the growth of wage fund in 1995 while Ukraine did so at the end of 1996. Until 2004, Ukraine had consistently higher marginal personal income tax rates and indirect income taxes paid by enterprises than Russia.
} 
2003). In contrast, skill wage inequality in Ukraine did not increase as much over the same period and returns to schooling were among the lowest among countries of Central and Eastern Europe. This observation of low reform progress and concurrent low returns to schooling in Ukraine is consistent with the recent finding of Fleisher, Sabirianova, and Wang (2004) on the positive effect of the speed of market reforms on a country's returns to schooling.

Our approach in analyzing the sources of cross-country differences in returns to schooling is to compare the Mincerian earnings functions between the two countries and then to use semiparametric decomposition techniques in the spirit of Juhn, Murphy, and Pierce (1993). We construct counterfactual distributions of log wages for university and secondary school graduates for Ukraine using the distributions of Russian characteristics, returns to characteristics, and unobservables. These counterfactual distributions provide an estimate of the distributions of Ukrainian log wages that would have prevailed if Ukraine had the same features as Russia. This allows us to decompose differences in returns to schooling between the two countries into shares due to differences in the labor market returns (price effect), differences in unobservables (residual effect), and differences in the labor force composition (composition effect).

This study is the first to provide the long series of the estimates of the returns to schooling in Russia and Ukraine starting from the planning period. In our comparative analysis, we use Russian and Ukrainian Longitudinal Monitoring Surveys covering a period from 1985 to 2002. In addition to the institutional comparability between the two countries, our study also benefits from the definitional comparability between the two surveys. Most of the key variables have similar definitions, and the estimated earnings functions have the same specifications. Thus, our study avoids a common problem in cross-country studies, where the differences in the estimated parameters are influenced by the discrepancies in the quality of data, estimation methods, and definitions of variables. ${ }^{4}$ In the next section of the paper, we describe in detail the data and variables used in the empirical analysis.

\section{Russian and Ukrainian Longitudinal Monitoring Surveys}

The data for this study are pooled from the two household surveys - Russian Longitudinal Monitoring Survey (RLMS) and Ukrainian Longitudinal Monitoring Survey

\footnotetext{
${ }^{4}$ Useful discussion of this problem in emerging markets is provided by Behrman and Rosenzweig (1994) and Srinivasan (1994).
} 
(ULMS). ${ }^{5}$ We use the second wave of RLMS that started in 1994, with 4,781 dwelling units selected by a three-stage stratified clustered sampling method and with 3,973 households responded. In the subsequent years of survey (1995-1996, 1998, 2000-2002), the new households that moved to the initially sampled dwellings were added and the old households that moved from the original sample to the new address were followed up, whenever possible. The sample size varies from year to year. For example, there were 8,893 individuals who completed the adult questionnaire in 1994, 8,342 in 1996, 8,701 in 1998, 9,074 in 2000, and 10,497 in 2002. To ensure the representativeness of cross-sections in our analysis, we have to exclude those respondents that moved from the original sample. ${ }^{6}$ This leaves us with 8,122 respondents in 1996, 7,894 in 1998, 7,568 in 2000, and 7,875 in 2002, and we base our wage analysis on a sample of 3,384-4,415 employed adults who have complete information on wages, education, and demographic characteristics (see Table A1). The RLMS 2000 also contains a series of retrospective questions regarding jobs held in 1985 and 1990. The number of persons who responded to the questions on wages in 1985 was 4,230 and in 1990 was 3,976.

The Ukrainian survey is based on a stratified random nationally representative sample of 4,096 households. Unlike RLMS, ULMS started only in 2003. To fill out the lack of labor force data in Ukraine in the 1990s, ULMS has gathered employment histories for 1986, 1991, and continuously from 1997 to 2003. 8,641 individuals of age 15-72 participated in the Ukrainian survey. The response rate was $66 \%$ for households and $87 \%$ for individuals within the households. The sample of employed with non-missing values on wages, education, and demographic characteristics ranges from 2,958 in 1998 to 4,197 in 1986. The sample construction is explained in Appendix Table A1.

Both surveys contain rich information on household and individual characteristics, albeit their focus is somewhat different. RLMS focuses more on household behavior and has extensive sections on household income and expenditures, health, nutrition, children and women issues,

\footnotetext{
${ }^{5}$ RLMS has been organized by Barry Popkin and conducted by the Consortium led by the Carolina Population Center in collaboration with the Institute of Sociology at the Russian Academy of Sciences, Moscow. ULMS has been organized by Hartmut Lehmann and carried out by the Consortium led by the Institute for the Study of Labor (IZA), Bonn in collaboration with the Kyiv International Institute of Sociology. We are very thankful to both teams for their excellent work.

${ }^{6}$ We find that the estimates of the returns to schooling are not affected by excluding respondents that moved from the original sample. We re-estimated the standard Mincerian earnings function (see Section 3) on a larger sample by adding a dummy for movers and its interaction with years of schooling. In all years, we did not find statistically significant (at the $10 \%$ level) differences in wages and returns to schooling associated with respondents' moving from the original sample.
} 
whereas ULMS devotes a significant portion of its questionnaire to the retrospective histories of employment, education, and migration. Despite these differences between the questionnaires, the two surveys provide a consistent set of the individual characteristics required for our analysis. These characteristics include individual earnings, hours of work, education, demographics, job tenure, and characteristics of the primary employer such as ownership and size.

The definitions of all variables used in the empirical analysis are provided in Appendix Table A2. Most of the individual attributes have identical definitions in both surveys, e.g. gender, age, potential labor market experience, job tenure, average weekly hours of work, and capital. In a few cases, an original variable has been modified to make it comparable between the surveys. For example, the continuous variable of the employer size from RLMS has been recoded into a categorical variable, with the same size categories as in ULMS. Detailed information on firm ownership from ULMS has been aggregated into the three broad categories of ownership available in RLMS: foreign (including domestic firms with some foreign capital); private (including self-employed, cooperatives, fully and partially privatized enterprises, and newly established private enterprises); and state (including budgetary organizations, state enterprises, local municipal enterprises, and state and collective farms).

Both Russian and Ukrainian data contain very detailed information on formal schooling, including the type of schools, actual years of studies, obtained degrees, and the date of school completion. At least two alternative measures of the years of schooling can be constructed for the years of survey: the actual years of studies from all schools attended and the adjusted years of schooling that are imputed from the number of years required for the highest degree obtained. For the retrospective years (1985-1991), however, only the latter measure can be imputed accurately on the base of the date of school completion, and we employ this second measure in most of our empirical analysis. The correlation between these two measures of schooling is relatively high (e.g. in 2002, the simple correlation coefficient is 0.900 in Russia and 0.895 in Ukraine). The results of the sensitivity analysis for the choice of schooling variables will be discussed below.

The dependent variable in our analysis is a log of monthly contractual (accrued) wage after taxes at the primary job. Using contractual wage in the earnings functions is generally preferred over the wages received in some short reference period (e.g. month), especially during 
the periods of mass wage delays and high volatility in wage payments that both countries experienced in the 1990s. ${ }^{7}$ Wages actually received in the last month is often zero when the wage debt accumulates and it could be much higher than the contractual wage when the debt is paid back. In ULMS, the measure of net contractual wages is available for all years for both employees and self-employed. Wages received in a different currency are converted into Ukrainian hryvnyas (UAH). ${ }^{8}$ In RLMS, this measure is available only for employees and only for 1998-2002. For 1994-1996, we have followed the method of Earle and Sabirianova (2002), imputing the contractual wage for workers with wage arrears as the ratio of the total wage debt to the number of monthly wages owed. For workers without wage arrears the contractual wage is considered to be the actual after-tax monthly wage received in cash or in kind in the last 30 days from the primary job. This measure of actually paid earnings is also used for self-employed in 1994-2002.

For the Soviet period of our data, the definitions of wages in both countries are the same. The main concern here is the presence of a recall bias. Do people actually remember what wages they received 17 or even 10 years ago? An econometrician might argue that because wage is the dependent variable, the recall bias should not affect the results as long as it can be assumed as an additive white noise. We can also add that the Soviet practice of wage payments according to the rigid wage grid, nearly zero inflation and strong attachment of a Soviet worker to one job are likely to reduce the recall error (Munich, Svejnar and Terrell, 2005a). Importantly, three of the four selected years are memorable, pivotal points in the Soviet history. In 1985 Gorbachev came to power and perestroika began, in 1986 the Chernobyl catastrophe in Ukraine shook the world, and in 1991 Gorbachev resigned, the Soviet Union ended, and Russia and Ukraine began their new independent history. Figure 1 shows that the shape of wage distributions in 1985/1986 is very similar between the two countries. The similarity is remarkable given the fact that the two samples are drawn independently in different years and the recall period is one year and half longer in Ukraine than in Russia. The mean wages from the surveys ( $w_{\mathrm{SAM}}$ ) are also close to the mean wages from the national statistical yearbooks $\left(w_{\mathrm{NSY}}\right)$ for corresponding years $\left(w_{\mathrm{SAM}, 85}=207\right.$

\footnotetext{
${ }^{7}$ Note that contractual wage also has shortcomings since it implicitly assumes zero costs associated with the delay of payments and that all arrears will be paid back. Ideally, we would like to use wages actually received during longer time period (e.g., 6 or 12 months). The ULMS dataset provides such a variable but only in the last year. In Section 4, we discuss how the estimates are sensitive to the alternative measures of wages.

${ }^{8}$ Ukraine had rubles till 1992, karbovancy in 1992-1996, and hryvnyas after 1996. People may also receive wages in a foreign currency, typically U.S. dollars.
} 
and $w_{\mathrm{NSY}, 85}=199$ for Russia and $w_{\mathrm{SAM}, 86}=173$ and $w_{\mathrm{NSY}, 86}=174$ for Ukraine). All of these facts combined suggest that it is plausible to approximate the true wage distributions in the Soviet period by the wages reported retrospectively. Yet, even if the errors of recall are present in the data, they should not bias the results in the direction of one country or the other. ${ }^{9}$

Another important issue in retrospective surveys is the under-representation of older age groups due to their higher mortality. To reduce the potential effect of the mortality-related sample attrition on the estimates of returns to schooling, we restrict our analysis to the prime age group 15-59 (the sample size is given in Appendix Table A1), and for the Soviet period of our data we employ the sample weights that are constructed on the base of the USSR Census 1989, with under-represented groups receiving larger weights. We use the sample weights for more recent years as well but their effect on the results is not statistically significant, as we show below.

Table 1, Appendix Table A3, and Figure 1 report the summary statistics for both surveys. It is evident that Russia and Ukraine exhibit very similar labor force characteristics during the pre-reform and reform periods. For example, mean adjusted years of schooling are identical in Russia and Ukraine in 1985/1986 and differ only by 0.6 years in 2002. ${ }^{10}$ The average length of the workweek is about 41-43 hours and the mean labor market experience is around 21 years in both countries. Gender and urban compositions are similar too. At the same time, tenure is longer in Ukraine than in Russia by 0.8-1.6 years. Although certain differences are noticeable with respect to firm characteristics (Ukraine has a higher share of the employed in very large enterprises and in the state sector), an increase in the share of workers in private and foreignowned firms and small businesses is apparent in both countries. Table A3 results suggest that the supply changes are unlikely to explain the different time paths in returns to schooling between the two countries because of very similar dynamics in workers' educational attainment. In both countries the share of workers with university degrees has been continuously growing at

\footnotetext{
${ }^{9}$ It is difficult to determine the sign of the bias generated by the recall errors in variables because the recall error is likely to be mean reverting especially in wages (see Kim and Solon, 2005). We can expect however that the size of the recall error is negatively correlated with memory and thus, the error is increasing with age and decreasing with education. This implies that coefficients on schooling are likely to be less downward biased than coefficients on tenure and labor market experience. In any case there is no reason to believe that this should bias the results towards one of the countries we compare.

${ }^{10}$ The reported differences in the actual years of schooling between the two countries could be due to the fact that ULMS specifically asks respondents to not count interruptions during the study such as maternity leave or required army service while in RLMS respondents might have included these breaks in the total years of schooling.
} 
the same rate and the share of low-education workers experienced a declining trend. Finally, Figure 1 documents another notable fact - starting from essentially identical shapes of wage distributions in 1985/1986, Russian and Ukrainian wage distributions significantly diverged over the transition period, with Russia having considerably higher levels of overall wage inequality.

\section{Earnings Function Analysis}

In this section, we compare the estimates of the Mincerian earnings functions in Russia and Ukraine and present the results of sensitivity analysis to show how robust the obtained returns to schooling are to the choice of specifications, variables, and methods used.

We begin by estimating the basic Mincerian earnings function with a standard set of covariates available for both countries and all years: ${ }^{11}$

$$
\ln w_{i t}=\beta_{0}+\beta_{1} \operatorname{sch}_{i t}+\beta_{2} \exp _{i t}+\beta_{3} \exp _{i t}^{2}+\beta_{4} \text { female }_{i t}+\beta_{5} \text { capital }_{i t}+\varepsilon_{i t},
$$

where $i$ indexes individuals, $t$ indexes time, $w_{i t}$ is monthly contractual wages after taxes at the primary job, $s c h_{i t}$ is adjusted years of schooling, $\exp _{i t}$ is years of potential labor market experience, female $_{i t}$ is a dummy variable indicating if an individual is female, capital $_{i t}$ is a dummy variable indicating if an individual $i$ lives in the capital city, and $\varepsilon_{i t}$ is an independently distributed error term. Definitions of the variables are in Appendix Table A2.

The OLS estimates of Eq.1 for Russia and Ukraine are presented in Table 2, Panel A and Panel B respectively. Until 1991, returns to schooling were similar for Russia and Ukraine, with $2.8-3.4 \%$ in $1985 / 1986^{12}$ and $3.9 \%$ in $1990 / 1991$. With the demise of the Soviet Union, however, schooling returns significantly diverged: in Russia they increased sharply to $8.1 \%$ in 1996, and then to 9.2\% in 2002 while in Ukraine they barely changed reaching 4.5\% in 2002.

As in a typical Mincerian earnings equation, the estimated returns to potential experience are concave. But compared to the estimates from the United States, the wage-experience profiles are flatter and average returns to labor market experience are relatively small. ${ }^{13}$ The small experience effect could be caused by the changing nature of the transition economies that reward

\footnotetext{
${ }^{11}$ We restrict our analysis to the years that are available for both countries, that is 1985(1986), 1990(1991), 1996(1997), 1998, 2000, and 2002.

${ }^{12}$ The difference in returns to schooling between the two countries in 1985/1986 is not statistically different from zero.

${ }^{13}$ This result is consistent with earlier studies by Flanagan (1998) and Rutkowski (1997) who also documented low returns to labor market experience in Czech Republic and Poland.
} 
younger, more mobile, and more adaptive people. It also appears that the experience profile is less concave in Ukraine than in Russia.

The male wage premium is significantly larger in Russia than in Ukraine. Although the gender wage gap fell in Russia from 53\% in 1998 to 47\% in 2002, it is still much higher than the gap during the Soviet time in both Russia and Ukraine (41\% in 1991) and during the transition period in Ukraine (40-42\%). The wage premium for living in a capital city is high in both countries. However, if in Ukraine this premium stays approximately constant at 30\% over 19912002, the premium for living in Moscow exhibits a continuous increase from 14\% in 1990 to $63 \%$ in $2002 .{ }^{14}$

As a complement to OLS estimates, we present the estimates of returns to schooling obtained from the series of quantile regressions (Koenker and Bassett, 1978). While the OLS method produces only mean prices of observable characteristics, quantile regressions can produce the whole distribution of returns to schooling. This allows us to see whether observed changes in schooling returns are uniform or concentrated in certain groups. Formally, we estimate the basic Mincerian function as in Eq.1:

$$
Q_{k}\left(\ln w_{i t} \mid X_{i t}\right)=\beta_{0}^{(k)}+\beta_{1}^{(k)} \operatorname{sch}_{i t}+\beta_{2}^{(k)} \exp _{i t}+\beta_{3}^{(k)} \exp _{i t}^{2}+\beta_{4}^{(k)} \text { female }_{i t}+\beta_{5}^{(k)} \text { capital }_{i t},
$$

where $Q_{k}\left(\ln w_{i t} \mid X_{i t}\right)$ denotes the $k^{\text {th }}$ percentile of distribution of log wages conditional on the covariate matrix $X_{i t}$ and $\beta_{j}^{(k)}$ is the $k^{\text {th }}$ percentile estimate of the slope of variable $j$. For each percentile $k$, country, and period (1985/1986, 1990/1991, 1996/1997, and 2002), we estimate Eq.2 and plot the obtained distributions of returns to schooling in Figure 2. Again we see the growing differences in returns to schooling between Russia and Ukraine. It is interesting that the cross-country differences were more pronounced in the middle of distribution in 1996/1997. By 2002, however, the bottom percentiles in Russia exhibited the largest increase in returns to schooling implying that having additional education at the bottom of wage distribution makes people significantly better off.

This first analysis of the data indicates that Russia and Ukraine during the Soviet period had very similar shapes of wage distributions, composition of labor force, returns to schooling,

\footnotetext{
${ }^{14}$ The relatively low "Moscow" premium during the Soviet period could be explained by the fact that, unlike other Soviet republics, Russia had many territories where workers were compensated for living in unfavorable climate conditions. The base "Moscow" salary was simply multiplied by "the regional wage coefficient", thus compressing the average Moscow premium. The high premium afterwards could be resulted from the system of living permits that drives the overall wages in the capital up.
} 
and returns to other observable characteristics. Within a few years of reforms, however, the differences in prices of observable characteristics, including returns to schooling, became apparent. Below we further investigate this divergence using a larger set of explanatory variables that are available for 1996-2002 years. In particular, the estimated specification is

$$
\begin{aligned}
\ln w_{i t}= & \beta_{0}+\beta_{1} \text { sch }_{i t}+\beta_{2} \exp _{i t}+\beta_{3} \exp _{i t}^{2}+\beta_{4} \text { female }_{i t}+\beta_{5} \text { capital }_{i t}+ \\
& +\beta_{6} \text { ten }_{i t}+\beta_{7} \text { ten }_{i t}^{2}+\sum_{n=1}^{q} \alpha_{k} \text { own }_{n, i t}+\sum_{m=1}^{p} \gamma_{m} \operatorname{size}_{m, i t}+\varepsilon_{i t}
\end{aligned}
$$

where $\operatorname{ten}_{i t}$ is years of tenure at the primary job, $o w n_{n, i t}$ is a set of dummies for state, private, and mixed ownership types, size $_{m, i t}$ is a set of dummies for the (employment) size categories of the firm an individual $i$ works for. ${ }^{15}$

The estimates of augmented Mincerian earnings function are presented in Table 3. The overall trend and the levels of returns to schooling remain qualitatively the same as in the basic Mincerian earnings function shown in Table 2. Again we see that rates of return rose sharply in Russia and hardly changed in Ukraine over the transition period. Controlling for tenure and firm characteristics does not affect returns to labor market experience but reduces gender wage differences and a premium for living in a capital city by approximately five percentage points in both countries. The obtained insignificant tenure effect could have been expected especially during the early reform period as accumulated firm-specific human capital becomes obsolete in the new economic environment. What is surprising is that after ten years of transition the return to tenure has not recovered to even $0.5 \%$. Perhaps workers with long tenures continue to be associated with inefficient state firms and lack up-to-date skills.

Firm characteristics significantly contribute to explaining variation in wages. There are important differences in wages across ownership types. In both countries, foreign-owned firms pay the highest wages ceteris paribus, followed by private firms, while the state sector has the lowest wages. But the non-state/state wage gap is somewhat larger in Russia than in Ukraine. Specifically, workers in foreign-owned enterprises earn 42\%-54\% more in Russia and 39\%-45\% more in Ukraine relative to state-owned enterprises (SOEs). Likewise, private-owned firms pay

\footnotetext{
${ }^{15}$ We have also estimated more flexible functional forms of the earnings functions allowing the returns to schooling to vary by gender and by ownership type. In both countries and in all years, we can not reject the null hypothesis that the coefficients on interactions of years of schooling with dummies for ownership type and gender equal to zero at the standard significance levels. The lack of variation in returns to schooling by ownership type is consistent with the hypothesis that an increase in schooling returns in transition economies is common for all sectors and is driven by market rather than by ownership effect (see Munich, Terrell and Svejnar, 2005b).
} 
their workers 30-40\% and 16-26\% more in Russia and Ukraine, respectively, compared to SOEs. Our estimates also demonstrate a significant and increasing over time employer size-wage effect. $^{16}$ To some extent, this result is surprising given that large firms suffered the most from disorganization caused by the collapse of the command economy (Blanchard and Kremer, 1997). Perhaps our observations reflect the late stage of transition when disorganization gradually diminishes and surviving large firms recover their competitiveness and start paying wage premium over small firms again.

We check the sensitivity of the obtained estimates of returns to schooling by relaxing sample restrictions, employing different definitions of the key variables, and including other controls to the baseline equation (Eq.1). Table 4 presents the results of the sensitivity analysis. The estimates appear to be insensitive to the sample weights in both countries and to the age restrictions of the sample in ULMS (which is upper-bounded to 72 years old). In RLMS, including older age groups reduces the estimated rates of return by 0.1-0.8 percentage points.

Alternative definitions of schooling and wages do change the schooling returns but do not affect the overall trends and conclusions. Using actual years of schooling instead of adjusted years of schooling raises the estimates of returns to schooling by 0.4-1.0 percentage points for Ukraine and decreases the estimates by 1.2-1.3 percentage points for Russia. The wage measure that we criticized earlier for its non-random volatility - wages actually received last month reduces the baseline estimates by 0.1-1.6 percentage points in Russia and increases it by 0.5 percentage points in Ukraine. The returns to schooling estimates based on earnings actually received during the last six months (available only in Ukraine) are very close to the estimates obtained using contractual wage. In both countries having hourly wage rate as a dependent variable produces higher estimates of returns to schooling relative to the baseline estimates.

A few additional variables, which are not available for both countries and for all years, are also included in the earnings functions to check if the results are sensitive to the inclusion of these variables (see Table 4). For Russia, we find that industry dummies practically do not affect the rates of returns but district fixed effects reduce the estimates of returns to schooling significantly by up to 2.1 percentage point. It is unlikely however that the district effect on returns to schooling would be different in Ukraine if this variable were available.

\footnotetext{
${ }^{16}$ This result is consistent with the positive size-wage gap documented in the U.S. literature. Traditional explanations of the positive size-wage gap appeal to higher productivity of large firms, selection of better workers, higher monitoring costs, rent-sharing, and efficiency wages to prevent shirking (see Oi and Idson, 1999).
} 
Family background variables are often used as a control variable for unobserved ability or as an instrument to correct for the possible endogeneity of schooling due to measurement error and omitted ability variables (see Card, 1995; Ashenfelter and Zimmerman, 1997). Because the downward biases resulting from measurement error are often bigger than the upward omitted ability biases, OLS estimates are typically lower than IV estimates (e.g., see Angrist and Krueger, 1991; Card, 2001). ${ }^{17}$ Unfortunately, only the Ukrainian survey has information on parental education and occupation. Even so it is unlikely that the family background effect on Russian returns to schooling is significantly different. We first use parental education and occupation (defined in Appendix Table A2) as control variables and receive a fairly standard result of the smaller estimates of schooling returns after controlling for ability proxies. Next we use family background together with age and age squared as instruments for years of education and labor market experience. ${ }^{18}$ Table 4 shows that IV estimates of returns to schooling increase from $7.3 \%$ in 1986 to $9.2 \%$ in 1991 and then further increase to $12.0 \%$ in 2002 . These numbers are considerably larger than the corresponding OLS estimates, which is consistent with studies for other transition economies (see Heckman and Lee, 2003, for China; Filer et al., 1999, for Czech and Slovak Republics).

To summarize, although in some instances returns to schooling appear to be sensitive to the choice of variables and specifications, these should not affect the overall finding of the divergence in rates of returns between Russia and Ukraine.

Conceptually, the estimates we obtained so far depict gross monetary returns to schooling. But what if low Ukrainian monetary returns are compensated by the higher nonmonetary benefits of schooling or its lower direct costs, thus leading to the higher net value of education? For example, part of the returns to schooling may occur in the form of lower unemployment rate. Simple descriptive statistics show that this is a valid statement in both countries but the relative difference in unemployment rates between university and secondary school graduates is much higher in Russia than in Ukraine. The unemployment rate in 2002 for individuals with a university degree was $4.5 \%$ in Russia and $8 \%$ in Ukraine while for individuals with secondary education it was 9.1\% in Russia and 12.3\% in Ukraine (ILO, 2004; Goskomstat,

\footnotetext{
${ }^{17}$ Card (2001) also discusses several other explanations of larger IV estimates, including unobserved differences between the treatment and comparison groups, specification searching, and heterogeneity in returns to schooling.

${ }^{18}$ Sargan's test cannot reject validity of instruments at any reasonable significance level.
} 
2003). Russian educated workers, therefore, additionally benefit from schooling by having a lower probability of being unemployed than their Ukrainian counterparts.

The direct costs of education are another important factor that is often omitted in conventionally measured returns to schooling. Hypothetically, it is possible to have different gross returns but similar net returns if direct costs were significantly lower in Ukraine than in Russia. We follow Fleisher et al. (1996) in computing net returns to schooling as $\beta_{S C H} /(1+\alpha)$ where $\alpha$ is the ratio of the direct costs of education (e.g. tuition) to the indirect costs (i.e. forgone earnings). Specifically, we calculate $\alpha$ as follows

$$
\alpha=\frac{\sum_{k} T_{k} S_{k} \frac{N_{k}}{N}}{W(1-U)},
$$

where $N_{k} / N$ is the share of students enrolled in school type $k$ (e.g., universities, professional secondary schools, and general secondary schools), $T_{k}$ is annual tuition fees, $S_{k}$ is the share of students who pay for their education, $W$ is annual earnings, and $U$ is unemployment rate.

The computed value of $\alpha$ in 2002 is 0.063 in Russia and 0.081 in Ukraine. ${ }^{19}$ This implies that in order to obtain net returns to schooling, the estimated coefficient on years of schooling has to be multiplied by 0.941 in Russia and by 0.925 in Ukraine. Such a correction hardly changes the magnitude of the gap in returns to schooling between the two countries and does not influence any of the conclusions from the previous analysis.

\section{Sources of Differences in Returns to Schooling}

The salient finding of the previous section is that returns to schooling in Russia and Ukraine have considerably diverged since 1991. Although we cannot establish the causal link between the speed of reforms and returns to schooling, we can try to explain what is driving the cross-country differences in returns to schooling, in particular, returns to higher education. ${ }^{20}$

\footnotetext{
${ }^{19}$ The calculations are based on the following data in 2002: $W^{\mathrm{RUS}}=53844$ rubles, $W^{\mathrm{UKR}}=4512$ hryvnays, $U^{\mathrm{RUS}}=8.6 \%$, $U^{\mathrm{UKR}}=10.1 \%, T^{\mathrm{RUS}}=(22662,11475,5675)$ rubles, $T^{\mathrm{UKR}}=(1985,1100,900)$ hryvnays, $S^{\mathrm{RUS}}=(50.9 \%, 37 \%, 4 \%)$, $S^{\mathrm{UKR}}=(59 \%, 5.5 \%, 5.6 \%), N^{\mathrm{RUS}}=(5947.5,2585.5,18440)$ thousands of students, $N^{\mathrm{UKR}}=(2269.8,502.5,6350.1)$ thousands of students in universities, professional secondary schools, and general secondary schools, respectively (Goskomstat, 2002a and 2002b; Derzhkomstat, 2002; Verhovna Rada, 2004; and Ukrainian Ministry of Education, 2004).

${ }^{20}$ We are unaware of any method that could decompose the cross-country differences in returns to schooling as conventionally measured. In this section we will focus on the differences between university and secondary schooleducated workers instead of using continuous years of schooling.
} 
As a first step, we present graphs that show the difference in log wages between university- and secondary school-educated workers. Figure 3 shows kernel density estimates for log wages for Russia and Ukraine in 1985/1986 and 2002. The densities for university graduates are clearly to the right of the densities for secondary school graduates in both countries. The estimated mean skill gap of wages is much higher in 2002 than in 1985/1986, and it is much higher in Russia (0.439) than in Ukraine (0.271) in 2002. The difference between the two distributions can be interpreted as a measure of the university wage premium over secondary school diploma and formally can be written as:

$$
\begin{aligned}
& \Delta_{k} \ln w_{t}^{R U S} \equiv Q_{k}\left(\ln w_{h, t}^{R U S}\right)-Q_{k}\left(\ln w_{s, t}^{R U S}\right)=Q_{k}\left(X_{h, t}^{R U S} \beta_{h}^{R U S}+\varepsilon_{h}^{R U S}\right)-Q_{k}\left(X_{s, t}^{R U S} \beta_{s}^{R U S}+\varepsilon_{s}^{R U S}\right) \\
& \Delta_{k} \ln w_{t}^{U K R} \equiv Q_{k}\left(\ln w_{h, t}^{U K R}\right)-Q_{k}\left(\ln w_{s, t}^{U K R}\right)=Q_{k}\left(X_{h, t}^{U K R} \beta_{h}^{U K R}+\varepsilon_{h}^{U K R}\right)-Q_{k}\left(X_{s, t}^{U K R} \beta_{s}^{U K R}+\varepsilon_{s}^{U K R}\right),
\end{aligned}
$$

where $Q_{k}(x)$ denotes the $k^{\text {th }}$ percentile of variable $x, h$ and $s$ stand for higher and secondary education, respectively.

We illustrate this measure by plotting the difference in log wages between the two groups of workers at various percentiles of the distributions in Figure 4. Consistent with quantile regressions estimates of returns to schooling, the returns to a university degree are greater in Russia than in Ukraine, the university wage premium is generally decreasing with percentiles, and it is the largest at lower percentiles.

Next, we would like to see how imported Russian characteristics ( $X \mathrm{~s}, \beta \mathrm{s}$, and $\varepsilon s)$ could have changed the returns to a university degree in Ukraine. For this, we construct counterfactual distributions of log wages for university- and secondary school-educated workers for Ukraine using the distributions of Russian characteristics, returns to characteristics, and unobservables. These counterfactual distributions give an estimate of the distributions of Ukrainian log wages that would have prevailed if Ukraine had the same features as Russia. Using actual and constructed wage distributions, we then compute and compare actual and counterfactual skill (university) wage premia and find the contributions of observable and unobservable characteristics and returns to cross-country differences in wage skill premium.

In general form, the counterfactual skill wage premium at each percentile in Ukraine can be presented as

$$
\Delta_{k} \ln w_{t}^{U K R(m)} \equiv Q_{k}\left(\ln w_{h, t}^{U K R(m)}\right)-Q_{k}\left(\ln w_{s, t}^{U K R(m)}\right),
$$

with $m$ indicating the numeral of the corresponding counterfactual. 
To construct skill premium distributions, we first estimate earnings functions (Eq.3) for each country and for each level of schooling (university degree and completed secondary school) and then generate counterfactual wage distributions following the semiparametric method developed by Juhn, Murphy, and Pearce (1993, henceforth JMP).

For clarity, we succinctly write Eq.3 as

$$
\ln w_{r, t}^{c}=X_{r, t}^{c} \beta_{r}^{c}+\varepsilon_{r, t}^{c},
$$

where $t$ and $c$ index time period and country, respectively, $r=\{h, s\}$ denotes the highest attained level of schooling (higher education with university degree or completed secondary school), $w$ is monthly contractual wages after taxes at the primary job, $\boldsymbol{X}$ is a set of observable characteristics of individuals and firms, a stochastic error term $\varepsilon$ absorbs unobservable characteristics of individuals. The coefficients $\beta_{r}^{c}$ can be interpreted as prices for various observable characteristics of workers. In Table 5, we present the estimates of Eq.7 for university and secondary school graduates by country in 2002 .

For each level of schooling, we construct four counterfactual wage distributions:

1. Russian observables, Ukrainian prices, and Ukrainian unobservables: $\ln w_{r, t}^{U K R(1)}=X_{r, t}^{R U S} \beta_{r}^{U K R}+\varepsilon_{r}^{U K R(R U S)}$

2. Ukrainian observables, Russian prices, and Ukrainian unobservables: $\ln w_{r, t}^{U K R(2)}=X_{r, t}^{U K R} \beta_{r}^{R U S}+\varepsilon_{r}^{U K R}$

3. Ukrainian observables, Ukrainian prices, and Russian unobservables: $\ln w_{r, t}^{U K R(3)}=X_{r, t}^{U K R} \beta_{r}^{U K R}+\varepsilon_{r}^{R U S(U K R)}$

4. Ukrainian observables, Russian prices, and Russian unobservables: $\ln w_{r, t}^{U K R(4)}=X_{r, t}^{U K R} \beta_{r}^{R U S}+\varepsilon_{r}^{R U S(U K R)}$

The counterfactual unobservables are computed nonparametrically using the JMP method. Specifically, $\quad \varepsilon_{r, t}^{R U S(U K R)}=F_{R U S, r}^{-1}\left(F_{U K R, r}\left(\varepsilon_{r, t}^{U K R} \mid X_{r, t}^{U K R}\right)\right)$, where $\varepsilon_{r, t}^{R U S(U K R)}$ is Russian counterfactual residuals corresponding to an Ukrainian individual with the level of schooling $r$ at period $t$ conditional on characteristics $\boldsymbol{X}, \varepsilon_{r, t}^{U K R}$ is actual Ukrainian residual, $F_{R U S}^{-1}$ denotes the inverse cumulative distribution of Russian residuals, and $F_{U K R}$ denotes cumulative distribution of Ukrainian residuals. The formula for Ukrainian counterfactual residuals is reverse: 
$\varepsilon_{r, t}^{U K R(R U S)}=F_{U K R, r}^{-1}\left(F_{R U S, r}\left(\varepsilon_{r, t}^{R U S} \mid X_{r, t}^{R U S}\right)\right)$.

The difference between counterfactual wage distribution for the individuals with a university degree and counterfactual wage distribution for individuals with completed secondary education is the counterfactual university wage premium. We present actual and counterfactual distributions of university wage premium for 2002 in Figure 5.

The area between the actual university wage premium in Russia and its counterfactual premium in Ukraine (or the distance between the two distributions) can be used in assessing the relative contribution of each factor into observed differences in returns to university education. The factors that are more important should bring Ukrainian counterfactual distributions closer to the Russian actual distribution. To quantify the relative importance of each of the factors, we employ the following measure of the distance between the actual and counterfactual $(\mathrm{m})$ distributions in period $t\left(d_{t m}\right)$ :

$$
d_{t m}=\frac{1}{100} \sum_{k=1}^{100}\left|\Delta_{k} \ln w_{t}^{R U S}-\Delta_{k} \ln w_{t}^{U K R(m)}\right| .
$$

If distributions of wage premium coincide, then $d_{t m}=0$. The larger is the value of $d_{t m}$, the larger is the difference between the distributions, and therefore, the smaller is the contribution of the corresponding factor. We report the distance measure as well as the key percentiles and means of actual and counterfactual university premium for 2002 in Table $6 .{ }^{21}$

In the earlier discussion of the descriptive statistics, we noted that Russia and Ukraine have very similar observable characteristics. Not surprisingly, then we find that the differences in observable characteristics contribute very little to explaining the differences in the skill wage premium in all years. When Russian observable characteristics are rewarded according to Ukrainian pricing schedules (counterfactual 1), the mean skill premium and the distance measure barely change relative to the actual skill premium in Ukraine.

In contrast, when the Russian slopes are used to price the Ukrainian observable characteristics (counterfactual 2), the mean skill premium sharply increases from $27.1 \%$ to $42 \%$ in 2002 and the distance between the two distributions considerably shrinks. Note that the changes in prices do not uniformly increase the university premium. The highest increase in the

\footnotetext{
${ }^{21}$ Results for earlier years are very similar to those for 2002 and therefore not reported and available upon request.
} 
premium is at top percentiles (18 percentage points at the $90^{\text {th }}$ percentile) and the gain in premium is generally increasing with percentiles.

Because the mean of counterfactual residuals is close to zero, the counterfactual 3 does not significantly change the mean skill premium. However, unobservables tend to decrease the premium in the right tail of the distribution and increase it in the left tail thus making its shape closer to the actual university premium in the Russian data. This reduces the distance between the two distributions but not significantly (see Figure 5 and Table 6). Combining Ukrainian labor force composition with Russian prices for both observable and unobservable characteristics brings the counterfactual wage distributions (counterfactual 4) even closer to the actual distribution of Russian returns. Overall, it is clear that the differences in pricing schedules for observed characteristics play a major role in explaining skill premium differences between Ukraine and Russia.

\section{Conclusion}

In the present paper, we estimate and compare returns to schooling in Russia and Ukraine - two countries that belonged to the former Soviet Union and inherited similar institutions and starting conditions. We take advantage of the institutional comparability between the two countries and the definitional comparability between the two household surveys in order to examine the cross-country differences in returns to schooling during the 1985-2002 period. The key finding is that after the breakup of the Soviet Union returns to schooling significantly diverged between Russia and Ukraine. In 2002, the estimated returns to schooling were two times less in Ukraine (4.5\%) than in Russia (9.2\%). We show that this fact is remarkably robust to modifications in econometric specifications, definitions of variables, and weighting schemes. Furthermore, we show that the divergence is present not only in the average returns to schooling but also in the distributions of returns to schooling.

To understand what determines the disparity in returns to schooling, we apply semiparametric methods in constructing counterfactual wage distributions for university- and secondary school-educated workers and assess the changes in skill wage premium in response to changes in observable characteristics, prices, and residuals. We observe that both countries exhibit very similar skill composition and other characteristics of the labor force during the prereform and reform periods. We find that the difference in observable characteristics contributes 
very little to observed differences in the skill premium across countries. Our estimates thus indicate that the differences in returns to schooling are unlikely to be supply driven.

We also conclude that the cross-country differences in unobservable characteristics do not significantly contribute to understanding the differences in returns to schooling. When the Russian unobservable characteristics are combined with Ukrainian observable characteristics and Ukrainian prices, the shape of the distribution of the skill premium in Ukraine becomes closer to the one in Russia but the distance between the two distributions remains significant (although somewhat smaller). Perhaps common history, active migration of families between Russia and Ukraine, similar human capital and abilities, same preferences for higher education, and shared institutional and organizational practices are the factors that contribute to more or less similar unobservable characteristics in the two countries.

In contrast, the differences in prices of observable characteristics play a critical role. Had Ukrainian workers been rewarded according to Russian pricing schedules, the skill premium would be comparable to that in Russia. Why are prices (slopes) so much different between the two countries? The answer to this question awaits a separate study. The lower demand for educated labor, more limited labor mobility, higher separation costs, and the larger extent of trade unions in Ukraine are most likely determinants with a potential power to explain the differences in returns to schooling. 


\section{References}

Angrist, Joshua D., and Krueger, Alan B., "Does Compulsory School Attendance Affect Schooling and Earnings,” Quarterly Journal of Economics 106, 4: 979-1014, November 1991.

Ashenfelter, Orley and David Zimmerman, "Estimating of Return to Schooling from Sibling Data: Fathers, Sons and Brothers,” The Review of Economics and Statistics 79, 1: 1-9, February 1997.

Behrman, Jere R., and Rosenzweig, Mark R., “Caveat Emptor: Cross-Country Data on Education and the Labor Force,” Journal of Development Economics 44, 1: 147-171, June 1994.

Blanchard, Olivier, and Kremer, Michael, "Disorganization," Quarterly Journal of Economics 112, 4: 1091-1126, November 1997.

Brainerd, Elizabeth, “Winners and Losers in Russia’s Economic Transition,” American Economic Review 88, 5: 1094-1116, Dec.1998.

Card, David, “Using Geographic Variation in College Proximity to Estimate the Return to Schooling”, in Louis N. Christofides, E. Kenneth Grant and Robert Swidinsky, eds., Aspects of Labour Market Behavior: Essays in Honor of John Vanderkamp, Toronto: University of Toronto Press, 1995: 201-222.

Card, David, "Estimating the Return to Schooling: Progress on Some Persistent Econometric Problems,” Econometrica 69, 5: 1127-1160, September 2001.

Chase, Robert, “Markets for Communist Human Capital: Returns to Education and Experience in the Czech Republic and Slovakia,” Industrial and Labor Relations Review 51, 3: 401423, April 1998.

Derzhkomstat, Ukrainian Statistical Yearbook, Kyiv: Derzhkomstat, 2002.

Earle, John S., and Klara Sabirianova, "How Late to Pay? Understanding Wage Arrears in Russia,” Journal of Labor Economics 20, 3: 661-707, July 2002.

EBRD, Transition Report 2001.

Filer, Randall, Jurajda, Stepan, and Planovsky, Jan, "Education and Wages in the Czech and Slovak Republics during Transition,” Labour Economics 6, 4: 581-593, November 1999. Flanagan, Robert, "Were Communists Good Human Capitalists: the Case of the Czech Republic,” Labour Economics 5, 3: 295-312, September 1998. 
Fleisher, Belton M., Dong, Keyong, and Liu, Yunhua, "Education, Enterprise Organization, and Productivity in the Chinese Paper Industry," Economic Development and Cultural Change 44, 3: 571-87, April 1996.

Fleisher, Belton M., Sabirianova, Klara, and Wang, Xiaojun, "Returns to Skills and the Speed of Reforms: Evidence from Central and Eastern Europe, China, and Russia,” IZA Discussion Paper, No. 1182, June 2004.

Goskomstat, Labor and Employment in Russia, Moscow: RF Goskomstat, 2003.

Goskomstat, Education in Russia, Moscow: RF Goskomstat, 2002a.

Goskomstat, Russian Statistical Yearbook, Moscow: RF Goskomstat, 2002b.

Juhn, Chinhui, Murphy, Kevin M., and Pierce, Brooks, "Wage Inequality and the Rise in the Returns to Skill," Journal of Political Economy 101, 3: 410-442, June 1993.

Heckman, James J., and Li, Xuesong, "Selection Bias, Comparative Advantage and Heterogeneous Returns to Education: Evidence from China in 2000,” NBER Working Paper Series, No. 9877, July 2003.

ILO, Laborsta, 2004, database available at http://laborsta.ilo.org/.

Kim, Bonggeun, and Solon, Gary, "Implications of Mean-Reverting Measurement Error for Longitudinal Studies of Wages and Employment," forthcoming in The Review of Economics and Statistics, 2005.

(http://www.econ.lsa.umich.edu/ gsolon/workingpapers/kim.pdf).

Koenker, R., and Bassett, G., "Regression quantiles," Econometrica 46, 1: 33-50, January 1978.

Linn, Johanness F., "Ten Years of Transition in Central Europe and the Former Soviet Union: The Good News and the Not-So-Good News," in Mario I. Bleijer and Marko Skreb, eds., Transition: The First Decade, Cambridge: MIT press, 2001.

Munich, Daniel, Svejnar, Jan, and Terrell, Katherine, "Returns to Human Capital under the Communist Wage Grid and During the Transition to a Market Economy,” forthcoming in the Review of Economics and Statistics, 2005a.

Munich, Daniel, Svejnar, Jan, and Terrell, Katherine, “Do Markets Favor Women’s Human Capital More than Planners Did?” forthcoming in the Journal of Comparative Economics, 2005b. 
Oi, Walter, and Idson, Todd, "Firm Size and Wages," in Orley Ashenfelter and David Card, eds., Handbook of Labor Economics, Vol. 3b, pp. 2165-2214. Amsterdam: Elsevier Science, 1999.

Rutkowski, Jan, "Low Wage Employment in Transitional Economies of Central and Eastern Europe," MOCT-MOST: Economic Policy in Transitional Economies 7, 1: 105-130, 1997.

Sabirianova Peter, Klara, "Skill-Biased Transition: The Role of Market Institutions and Technological Change,” The Davidson Institute Working Paper Series, No. 616, October 2003.

Srinivasan, T.N., "Data Base for Development Analysis: An Overview” Journal of Development Economics 44, 1: 3-27, June 1994.

Ukrainian Ministry of Education, Education in Figures, 2004, (www.mon.gov.ua).

Verhovna Rada of Ukraine, Hearings on Higher Education in Ukraine, 2004, (http:// www.rada.gov.ua /zakon /new/par_sl/sl130504.htm). 
Table 1: Descriptive Statistics

Panel A: Russia

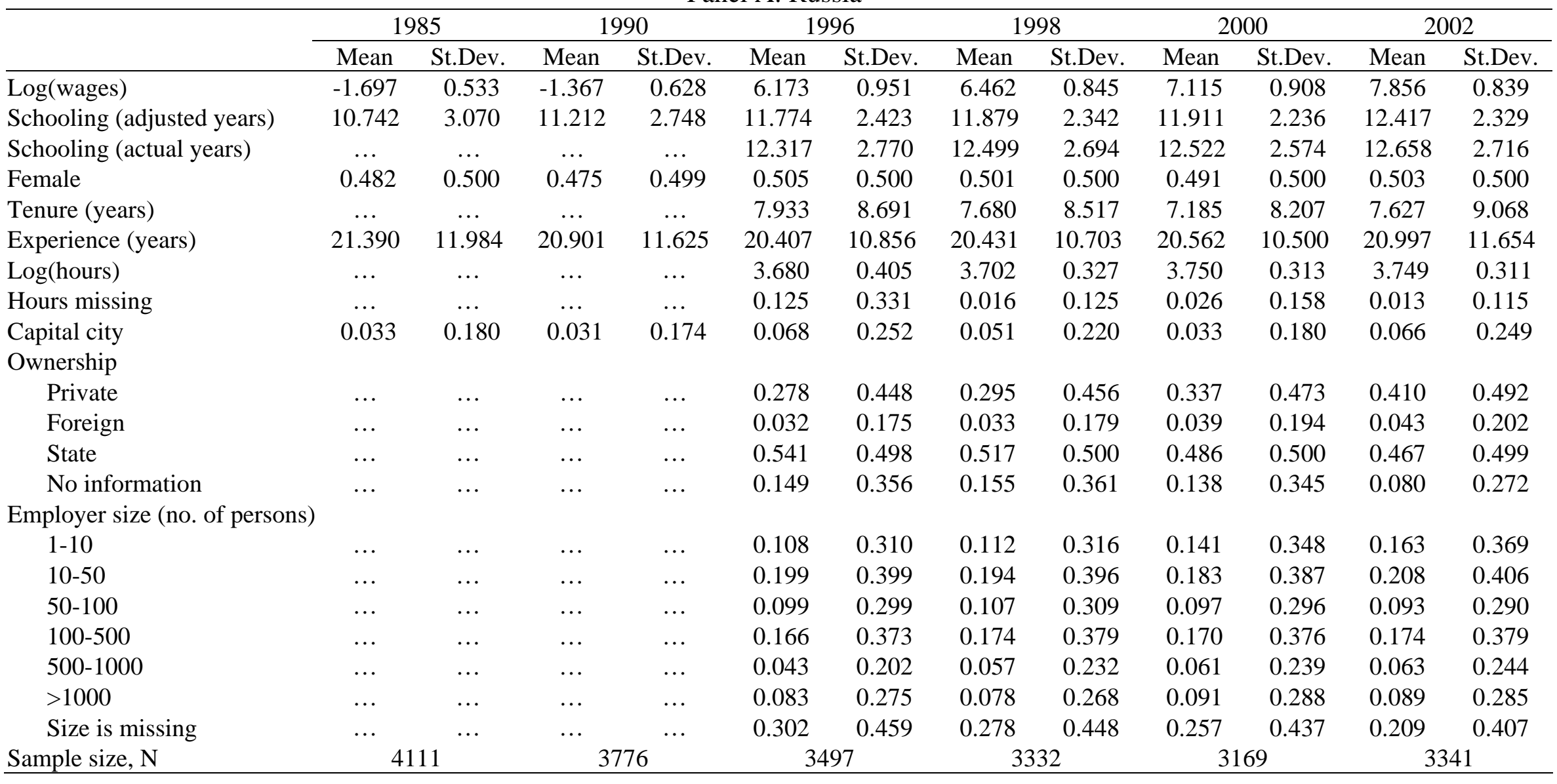


Table 1: continued

Panel B: Ukraine

\begin{tabular}{|c|c|c|c|c|c|c|c|c|c|c|c|c|}
\hline & \multicolumn{2}{|c|}{1986} & \multicolumn{2}{|c|}{1991} & \multicolumn{2}{|c|}{1997} & \multicolumn{2}{|c|}{1998} & \multicolumn{2}{|c|}{2000} & \multicolumn{2}{|c|}{2002} \\
\hline & Mean & St.Dev. & Mean & St.Dev. & Mean & St.Dev. & Mean & St.Dev. & Mean & St.Dev. & Mean & St.Dev. \\
\hline Schooling (adjusted years) & 10.750 & 2.892 & 11.157 & 2.559 & 11.612 & 2.361 & 11.688 & 2.275 & 11.822 & 2.239 & 11.849 & 2.217 \\
\hline Female & 0.496 & 0.500 & 0.483 & 0.500 & 0.537 & 0.499 & 0.539 & 0.499 & 0.538 & 0.499 & 0.530 & 0.499 \\
\hline Tenure (years) & 10.406 & 9.931 & 10.306 & 9.984 & 9.248 & 9.617 & 9.379 & 9.730 & 8.770 & 9.466 & 8.464 & 9.326 \\
\hline Experience (years) & 21.241 & 11.860 & 21.331 & 11.797 & 21.088 & 11.104 & 21.183 & 10.793 & 20.884 & 10.607 & 21.198 & 10.706 \\
\hline Capital city & 0.037 & 0.190 & 0.036 & 0.187 & 0.058 & 0.235 & 0.058 & 0.233 & 0.065 & 0.246 & 0.063 & 0.243 \\
\hline \multicolumn{13}{|l|}{ Ownership } \\
\hline Private & 0.104 & 0.305 & 0.154 & 0.361 & 0.224 & 0.417 & 0.242 & 0.428 & 0.276 & 0.447 & 0.298 & 0.457 \\
\hline Foreign & 0.005 & 0.071 & 0.009 & 0.095 & 0.015 & 0.120 & 0.013 & 0.112 & 0.015 & 0.120 & 0.016 & 0.127 \\
\hline State & 0.885 & 0.320 & 0.828 & 0.377 & 0.744 & 0.436 & 0.723 & 0.448 & 0.683 & 0.465 & 0.652 & 0.476 \\
\hline No information & 0.007 & 0.082 & 0.009 & 0.093 & 0.018 & 0.132 & 0.022 & 0.147 & 0.026 & 0.159 & 0.033 & 0.180 \\
\hline $100-500$ & 0.090 & 0.287 & 0.112 & 0.315 & 0.143 & 0.350 & 0.152 & 0.359 & 0.168 & 0.374 & 0.187 & 0.390 \\
\hline $500-1000$ & 0.031 & 0.174 & 0.031 & 0.172 & 0.042 & 0.201 & 0.044 & 0.205 & 0.051 & 0.220 & 0.062 & 0.241 \\
\hline$>1000$ & 0.073 & 0.260 & 0.089 & 0.284 & 0.117 & 0.321 & 0.126 & 0.332 & 0.136 & 0.343 & 0.150 & 0.357 \\
\hline Size is missing & 0.584 & 0.493 & 0.517 & 0.500 & 0.365 & 0.481 & 0.321 & 0.467 & 0.245 & 0.430 & 0.133 & 0.339 \\
\hline Sample size, $\mathrm{N}$ & \multicolumn{2}{|c|}{4191} & \multicolumn{2}{|c|}{3528} & \multicolumn{2}{|c|}{2946} & \multicolumn{2}{|c|}{2812} & \multicolumn{2}{|c|}{2925} & \multicolumn{2}{|c|}{3289} \\
\hline
\end{tabular}

Note. The sample for each country and year consists of observations with non-missing values for the variables used in the basic Mincerian wage function. 
Table 2: Basic Mincerian Earnings Functions, OLS

Panel A: Russia

\begin{tabular}{|c|c|c|c|c|c|c|}
\hline & 1985 & 1990 & 1996 & 1998 & 2000 & 2002 \\
\hline \multirow[t]{2}{*}{ Schooling (adjusted years) } & $0.028 * * *$ & $0.039 * * *$ & $0.081 * * *$ & $0.091 * * *$ & $0.093 * * *$ & $0.092 * * *$ \\
\hline & $(0.003)$ & $(0.004)$ & $(0.007)$ & $(0.006)$ & $(0.007)$ & $(0.006)$ \\
\hline \multirow[t]{2}{*}{ Experience (years) } & $0.019 * * *$ & $0.027^{* * *}$ & $0.014^{* * *}$ & $0.029 * * *$ & $0.045 * * *$ & $0.030 * * *$ \\
\hline & $(0.003)$ & $(0.003)$ & $(0.005)$ & $(0.005)$ & $(0.005)$ & $(0.005)$ \\
\hline \multirow[t]{2}{*}{ Experience $^{2} / 1000$} & $-0.378 * * *$ & $-0.554 * * *$ & $-0.335 * * *$ & $-0.629 * * *$ & $-0.991 * * *$ & $-0.724 * * *$ \\
\hline & $(0.055)$ & $(0.072)$ & $(0.119)$ & $(0.108)$ & $(0.129)$ & (0.119) \\
\hline \multirow[t]{2}{*}{ Female } & $-0.424 * * *$ & $-0.401 * * *$ & $-0.473 * * *$ & $-0.530 * * *$ & $-0.520 * * *$ & $-0.473 * * *$ \\
\hline & $(0.016)$ & $(0.020)$ & $(0.030)$ & $(0.027)$ & $(0.030)$ & $(0.026)$ \\
\hline \multirow[t]{2}{*}{ Capital } & 0.011 & 0.095 & $0.614^{* * *}$ & $0.537 * * *$ & $0.634 * * *$ & $0.630 * * *$ \\
\hline & $(0.044)$ & $(0.058)$ & $(0.060)$ & $(0.061)$ & $(0.082)$ & $(0.053)$ \\
\hline $\mathrm{N}$ & 4111 & 3776 & 3497 & 3332 & 3169 & 3341 \\
\hline \multirow[t]{3}{*}{$\mathrm{R}^{2}$} & 0.19 & 0.15 & 0.13 & 0.17 & 0.15 & 0.18 \\
\hline & & Panel B: Ul & raine & & & \\
\hline & 1986 & 1991 & 1997 & 1998 & 2000 & 2002 \\
\hline \multirow[t]{2}{*}{ Schooling (adjusted years) } & $0.034 * * *$ & $0.039 * * *$ & $0.037 * * *$ & $0.039 * * *$ & $0.038 * * *$ & $0.045^{* * *}$ \\
\hline & $(0.004)$ & $(0.005)$ & $(0.005)$ & $(0.005)$ & $(0.005)$ & $(0.005)$ \\
\hline \multirow[t]{2}{*}{ Experience (years) } & $0.012 * * *$ & $0.016 * * *$ & $0.019 * * *$ & $0.016 * * *$ & $0.016 * * *$ & $0.019 * * *$ \\
\hline & $(0.003)$ & $(0.004)$ & $(0.004)$ & $(0.004)$ & $(0.004)$ & $(0.004)$ \\
\hline \multirow[t]{2}{*}{ Experience $^{2} / 1000$} & $-0.230 * * *$ & $-0.320 * * *$ & $-0.436 * * *$ & $-0.395 * * *$ & $-0.415^{* * *}$ & $-0.502 * * *$ \\
\hline & $(0.063)$ & $(0.078)$ & $(0.084)$ & $(0.088)$ & $(0.090)$ & $(0.092)$ \\
\hline \multirow[t]{2}{*}{ Female } & $-0.418 * * *$ & $-0.434 * * *$ & $-0.423^{* * *}$ & $-0.423 * * *$ & $-0.413^{* * *}$ & $-0.398 * * *$ \\
\hline & $(0.016)$ & $(0.021)$ & $(0.022)$ & $(0.022)$ & $(0.021)$ & $(0.021)$ \\
\hline \multirow[t]{2}{*}{ Capital } & $0.159 * * *$ & $0.167 * * *$ & $0.267 * * *$ & $0.274 * * *$ & $0.301 * * *$ & $0.285 * * *$ \\
\hline & $(0.044)$ & $(0.057)$ & $(0.046)$ & $(0.047)$ & $(0.042)$ & $(0.043)$ \\
\hline $\mathrm{N}$ & 4191 & 3528 & 2946 & 2812 & 2925 & 3289 \\
\hline $\mathrm{R}^{2}$ & 0.20 & 0.15 & 0.14 & 0.14 & 0.14 & 0.13 \\
\hline
\end{tabular}

Note. Dependent variable is log of monthly contractual wages after taxes at the primary job. Robust standard errors are in parentheses; * significant at 10\%; ** significant at 5\%; *** significant at $1 \%$. Definitions of the variables are in Appendix Table A2. The sample weights are applied in Russia for all years and in Ukraine for 1986 and 1991. The sample is restricted to age 1559. The constant term is estimated but not shown here. 
Table 3: Augmented Mincerian Earnings Functions, OLS

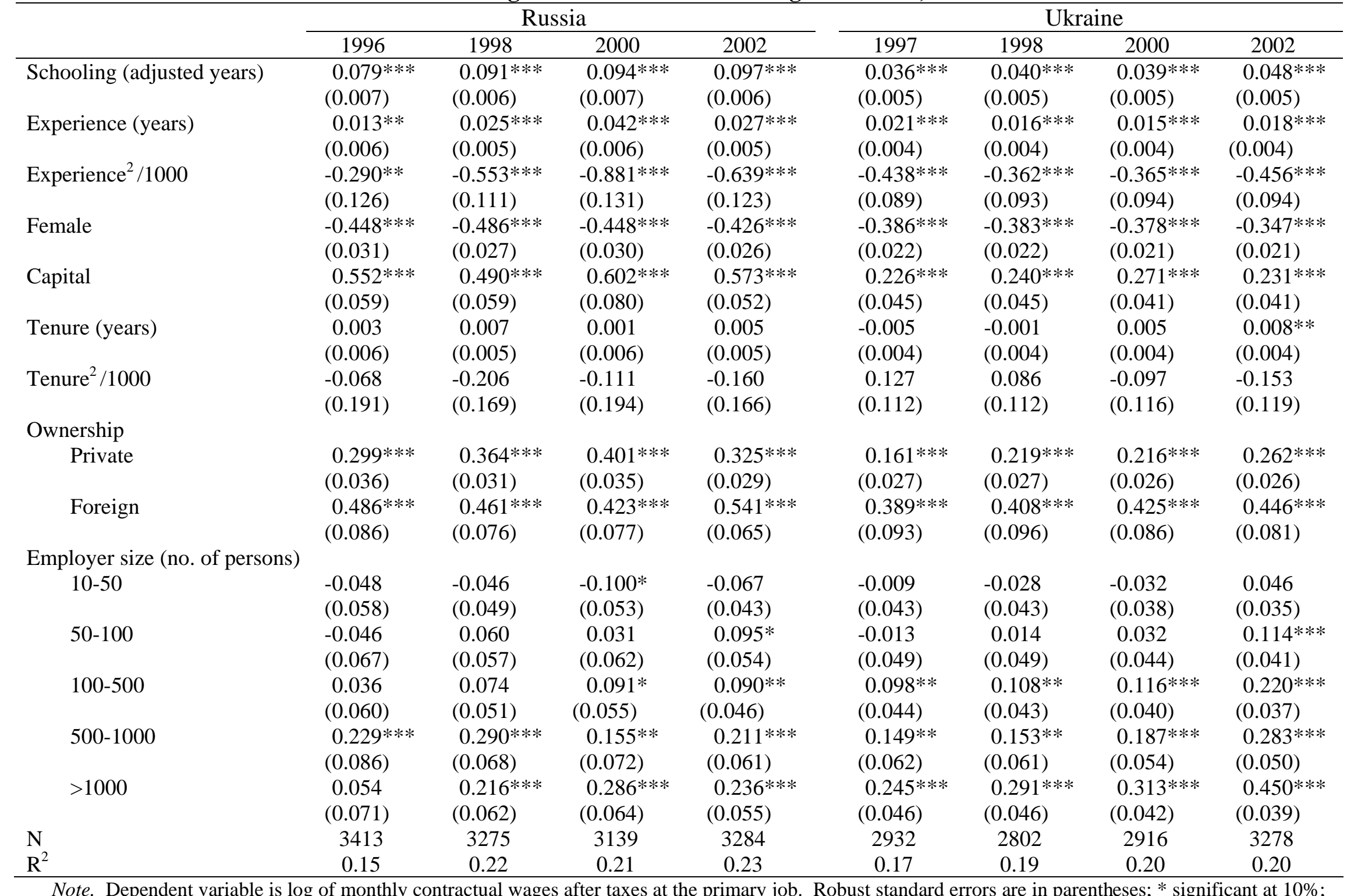

Note. Dependent variable is log of monthly contractual wages after taxes at the primary job. Robust standard errors are in parentheses; * significant at $10 \%$; ** significant at 5\%; *** significant at 1\%. Definitions of the variables are in Appendix Table A2. Sample weights are applied in Russia. The sample is restricted to age 15-59. Omitted categories are 1-10 (employer size) and state (ownership). Intercept and two dummy variables for missing employer size and missing ownership are included but not shown here. 
Table 4: Sensitivity Analysis of the Estimated Returns to Schooling

\begin{tabular}{|c|c|c|c|c|c|c|}
\hline \multicolumn{7}{|c|}{ Panel A: Russia } \\
\hline & 1985 & 1990 & 1996 & 1998 & 2000 & 2002 \\
\hline \multirow[t]{2}{*}{ Without survey weights } & 0.027 & 0.039 & 0.081 & 0.094 & 0.097 & 0.096 \\
\hline & $(0.003)$ & $(0.004)$ & $(0.007)$ & $(0.006)$ & $(0.007)$ & $(0.006)$ \\
\hline \multirow{3}{*}{ Without restrictions on age } & 0.027 & 0.037 & 0.077 & 0.083 & 0.086 & 0.089 \\
\hline & $(0.003)$ & $(0.004)$ & $(0.006)$ & $(0.006)$ & $(0.006)$ & $(0.006)$ \\
\hline & [4220] & [3964] & {$[3676]$} & [3537] & [3374] & [3531] \\
\hline \multirow[t]{3}{*}{ Schooling (actual years) } & $\ldots$ & $\ldots$ & 0.068 & 0.078 & 0.080 & 0.080 \\
\hline & & & $(0.006)$ & $(0.005)$ & $(0.006)$ & $(0.005)$ \\
\hline & & & [3469] & [3298] & [3159] & [3310] \\
\hline \multirow{3}{*}{$\begin{array}{l}\text { With wages actually } \\
\text { received last month }\end{array}$} & $\ldots$ & $\ldots$ & 0.065 & 0.090 & 0.092 & 0.086 \\
\hline & 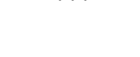 & & $(0.008)$ & $(0.009)$ & $(0.008)$ & $(0.007)$ \\
\hline & & & {$[2445]$} & {$[2326]$} & [2649] & [2906] \\
\hline \multirow{3}{*}{$\begin{array}{l}\text { With log of hourly wage } \\
\text { rate }\end{array}$} & $\ldots$ & $\ldots$ & 0.085 & 0.097 & 0.102 & 0.101 \\
\hline & & & $(0.007)$ & $(0.006)$ & $(0.007)$ & $(0.006)$ \\
\hline & & & [3061] & [3281] & [3090] & [3297] \\
\hline \multirow[t]{3}{*}{ With industry dummies } & 0.032 & 0.042 & 0.079 & 0.091 & 0.093 & $\ldots$ \\
\hline & $(0.003)$ & $(0.004)$ & $(0.006)$ & $(0.006)$ & $(0.007)$ & \\
\hline & [3982] & [3679] & [3477] & [3316] & [3132] & \\
\hline \multirow[t]{2}{*}{ With district fixed effects } & 0.023 & 0.030 & 0.063 & 0.069 & 0.073 & 0.074 \\
\hline & $(0.003)$ & $(0.004)$ & $(0.006)$ & $(0.005)$ & $(0.006)$ & $(0.005)$ \\
\hline
\end{tabular}

Panel B: Ukraine

\begin{tabular}{|c|c|c|c|c|c|c|}
\hline & 1986 & 1991 & 1997 & 1998 & 2000 & 2002 \\
\hline \multirow[t]{2}{*}{ Without survey weights } & 0.031 & 0.039 & 0.037 & 0.039 & 0.038 & 0.045 \\
\hline & $(0.003)$ & $(0.004)$ & $(0.005)$ & $(0.005)$ & $(0.005)$ & $(0.005)$ \\
\hline \multirow{3}{*}{$\begin{array}{l}\text { Without restrictions on } \\
\text { age }\end{array}$} & 0.034 & 0.039 & 0.040 & 0.040 & 0.035 & 0.046 \\
\hline & $(0.004)$ & $(0.005)$ & $(0.005)$ & $(0.005)$ & $(0.004)$ & $(0.004)$ \\
\hline & [4192] & [3564] & [3073] & [2945] & [3099] & [3494] \\
\hline \multirow[t]{3}{*}{ Schooling (actual years) } & $\ldots$ & $\ldots$ & 0.041 & 0.046 & 0.048 & 0.054 \\
\hline & & & $(0.005)$ & $(0.006)$ & $(0.005)$ & $(0.005)$ \\
\hline & & & [2914] & [2779] & [2892] & [3251] \\
\hline \multirow{3}{*}{$\begin{array}{l}\text { With wages actually } \\
\text { received last month }\end{array}$} & $\ldots$ & $\ldots$ & $\ldots$ & $\ldots$ & $\ldots$ & 0.050 \\
\hline & & & & & & $(0.005)$ \\
\hline & & & & & & [3066] \\
\hline \multirow{2}{*}{$\begin{array}{l}\text { With log of hourly wage } \\
\text { rate }\end{array}$} & $\ldots$ & $\ldots$ & $\ldots$ & $\ldots$ & $\ldots$ & $\begin{array}{c}0.051 \\
(0.005)\end{array}$ \\
\hline & & & & & & [2971] \\
\hline \multirow{3}{*}{$\begin{array}{l}\text { With wages actually } \\
\text { received over the last six } \\
\text { months }\end{array}$} & & & & & & 0.048 \\
\hline & & & & & & $(0.005)$ \\
\hline & & & & & & [2570] \\
\hline \multirow[t]{3}{*}{ Based on IV estimation } & 0.073 & 0.092 & 0.088 & 0.103 & 0.111 & 0.120 \\
\hline & $(0.010)$ & $(0.014)$ & $(0.014)$ & $(0.014)$ & $(0.014)$ & $(0.013)$ \\
\hline & [3764] & [3193] & [2722] & [2604] & [2731] & [3058] \\
\hline \multirow[t]{3}{*}{ With parents' background } & 0.031 & 0.034 & 0.032 & 0.030 & 0.029 & 0.038 \\
\hline & $(0.004)$ & $(0.005)$ & $(0.005)$ & $(0.005)$ & $(0.005)$ & (0.005) \\
\hline & [3766] & [3196] & [2742] & [2619] & [2748] & [3061] \\
\hline
\end{tabular}

Note. The table shows the estimated returns to schooling based on the alternative specifications of the basic Mincerian equation (shown in Table 2). Robust standard errors are in parentheses; all coefficients are significant at $1 \%$. The number of observations is in brackets if it is different from Table 2. 
Table 5: Earnings Functions for University and Secondary School Graduates, OLS, 2002

\begin{tabular}{|c|c|c|c|c|}
\hline & \multicolumn{2}{|c|}{ Ukraine } & \multicolumn{2}{|c|}{ Russia } \\
\hline & $\begin{array}{c}\text { University } \\
(1) \\
\end{array}$ & $\begin{array}{l}\text { Secondary } \\
\text { school } \\
(2) \\
\end{array}$ & $\begin{array}{c}\text { University } \\
(3) \\
\end{array}$ & $\begin{array}{c}\text { Secondary } \\
\text { school } \\
(4) \\
\end{array}$ \\
\hline Female & $\begin{array}{l}0.244 * * * \\
(0.045)\end{array}$ & $\begin{array}{l}0.350 * * * \\
(0.033)\end{array}$ & $\begin{array}{l}0.391 * * * \\
(0.051)\end{array}$ & $\begin{array}{l}0.446^{* * *} \\
(0.042)\end{array}$ \\
\hline Experience (years) & $\begin{array}{c}0.018 * \\
(0.009)\end{array}$ & $\begin{array}{l}0.014^{* *} \\
(0.006)\end{array}$ & $\begin{array}{l}0.041 \text { *** } \\
(0.010)\end{array}$ & $\begin{array}{l}0.024 * * * \\
(0.009)\end{array}$ \\
\hline Experience $^{2} / 1000$ & $\begin{array}{l}-0.424^{*} \\
(0.239)\end{array}$ & $\begin{array}{l}-0.357 * * \\
(0.146)\end{array}$ & $\begin{array}{l}-0.979 * * * \\
(0.268)\end{array}$ & $\begin{array}{c}-0.612 * * * \\
(0.203)\end{array}$ \\
\hline Capital & $\begin{array}{l}-0.037 \\
(0.074)\end{array}$ & $\begin{array}{l}0.355^{* * *} \\
(0.065)\end{array}$ & $\begin{array}{l}0.482^{* * * *} \\
(0.084)\end{array}$ & $\begin{array}{l}0.655^{* * *} \\
(0.090)\end{array}$ \\
\hline Tenure (years) & $\begin{array}{c}0.005 \\
(0.008)\end{array}$ & $\begin{array}{c}0.008 \\
(0.007)\end{array}$ & $\begin{array}{c}0.019 * \\
(0.010)\end{array}$ & $\begin{array}{l}-0.004 \\
(0.008)\end{array}$ \\
\hline Tenure $^{2} / 1000$ & $\begin{array}{l}-0.104 \\
(0.258)\end{array}$ & $\begin{array}{l}-0.222 \\
(0.219)\end{array}$ & $\begin{array}{l}-0.538 \\
(0.352)\end{array}$ & $\begin{array}{c}0.162 \\
(0.283)\end{array}$ \\
\hline Ownership & & & & \\
\hline Private & $\begin{array}{l}0.292 * * * \\
(0.062)\end{array}$ & $\begin{array}{l}0.253^{* * *} \\
(0.042)\end{array}$ & $\begin{array}{l}0.417 * * * \\
(0.057)\end{array}$ & $\begin{array}{l}0.334 * * * \\
(0.047)\end{array}$ \\
\hline Foreign & $\begin{array}{c}0.076 \\
(0.157)\end{array}$ & $\begin{array}{l}0.523^{* * *} \\
(0.115)\end{array}$ & $\begin{array}{l}0.745^{* * * *} \\
(0.127)\end{array}$ & $\begin{array}{l}0.677^{* * * *} \\
(0.107)\end{array}$ \\
\hline Employer size (no. & & & & \\
\hline $10-50$ & $\begin{array}{l}-0.049 \\
(0.091)\end{array}$ & $\begin{array}{c}0.024 \\
(0.061)\end{array}$ & $\begin{array}{l}-0.067 \\
(0.090)\end{array}$ & $\begin{array}{l}-0.024 \\
(0.068)\end{array}$ \\
\hline $50-100$ & $\begin{array}{c}0.125 \\
(0.094)\end{array}$ & $\begin{array}{c}0.012 \\
(0.076)\end{array}$ & $\begin{array}{l}-0.024 \\
(0.103)\end{array}$ & $\begin{array}{c}0.205^{* *} \\
(0.090)\end{array}$ \\
\hline $100-500$ & $\begin{array}{c}0.143 \\
(0.099)\end{array}$ & $\begin{array}{l}0.217^{* * *} \\
(0.061)\end{array}$ & $\begin{array}{c}0.130 \\
(0.094)\end{array}$ & $\begin{array}{c}0.091 \\
(0.072)\end{array}$ \\
\hline $500-1000$ & $\begin{array}{c}0.215^{*} \\
(0.124)\end{array}$ & $\begin{array}{l}0.308^{* * *} \\
(0.072)\end{array}$ & $\begin{array}{c}0.064 \\
(0.118)\end{array}$ & $\begin{array}{l}0.300^{* * *} \\
(0.094)\end{array}$ \\
\hline$>1000$ & $\begin{array}{l}0.370^{* * *} \\
(0.099)\end{array}$ & $\begin{array}{l}0.475^{* * *} \\
(0.064)\end{array}$ & $\begin{array}{c}0.005 \\
(0.109)\end{array}$ & $\begin{array}{l}0.413^{* * *} \\
(0.087)\end{array}$ \\
\hline Constant & $\begin{array}{l}5.224^{* * * *} \\
(0.120)\end{array}$ & $\begin{array}{l}4.852 * * * \\
(0.087)\end{array}$ & $\begin{array}{l}7.373^{* * * *} \\
(0.120)\end{array}$ & $\begin{array}{l}7.017^{* * * *} \\
(0.095)\end{array}$ \\
\hline $\mathrm{N}$ & 663 & 1375 & 753 & 1345 \\
\hline $\mathrm{R}^{2}$ & 0.16 & 0.19 & 0.25 & 0.20 \\
\hline
\end{tabular}

Note. Dependent variable is log of monthly contractual wages after taxes at the primary job. Robust standard errors are in parentheses; * significant at 10\%; ** significant at 5\%; *** significant at $1 \%$. Definitions of the variables are in Appendix Table A2. Sample weights are applied in Russia. The sample is restricted to age 15-59. Omitted categories are 1-10 (employer size) and state (ownership). Two dummy variables for missing employer size and missing ownership are included but not shown here. 
Table 6: Actual and Counterfactual Distributions of University Wage Premium, 2002

\begin{tabular}{|c|c|c|c|c|c|c|c|}
\hline & \multirow{2}{*}{ Mean } & \multirow{2}{*}{$d_{t m}$} & \multicolumn{5}{|c|}{ Selected Percentiles } \\
\hline & & & 10 & 25 & 50 & 75 & 90 \\
\hline \multicolumn{8}{|c|}{ Actual university wage premium } \\
\hline Russia & 0.439 & - & 0.628 & 0.382 & 0.337 & 0.319 & 0.379 \\
\hline Ukraine & 0.271 & 0.154 & 0.470 & 0.287 & 0.333 & 0.182 & 0.182 \\
\hline \multicolumn{8}{|c|}{ Counterfactual university wage premium for Ukraine } \\
\hline Counterfactual 1 & 0.277 & 0.158 & 0.458 & 0.290 & 0.235 & 0.186 & 0.180 \\
\hline Counterfactual 2 & 0.420 & 0.073 & 0.476 & 0.444 & 0.399 & 0.356 & 0.360 \\
\hline Counterfactual 3 & 0.277 & 0.138 & 0.499 & 0.303 & 0.303 & 0.136 & 0.117 \\
\hline Counterfactual 4 & 0.427 & 0.069 & 0.554 & 0.485 & 0.417 & 0.311 & 0.311 \\
\hline \multicolumn{8}{|c|}{$\begin{array}{l}\text { Note. The university premium is defined as the difference between wages of individuals with a university degree and } \\
\text { ges of individuals with completed secondary school. Counterfactual } 1 \text { corresponds to Russian characteristics and } \\
\text { rainian prices for observable and unobservable characteristics. Counterfactual } 2 \text { corresponds to Ukrainian } \\
\text { racteristics, Russian coefficients (prices) and Ukrainian unobservable characteristics. Counterfactual } 3 \text { corresponds to } \\
\text { rainian characteristics, Ukrainian coefficients (prices) and Russian unobservable characteristics. Counterfactual } 4 \\
\text { responds to Ukrainian characteristics, Russian coefficients (prices) and Russian unobservable characteristics (residuals) } \\
\text { onometric specification is as in Table } 5 . d_{t m} \text { is the distance between the actual Russian distribution and counterfactual } \\
\text { rainian distributions (computed as in Eg.8). }\end{array}$} \\
\hline
\end{tabular}


Figure 1: Wage Distributions, Russia and Ukraine

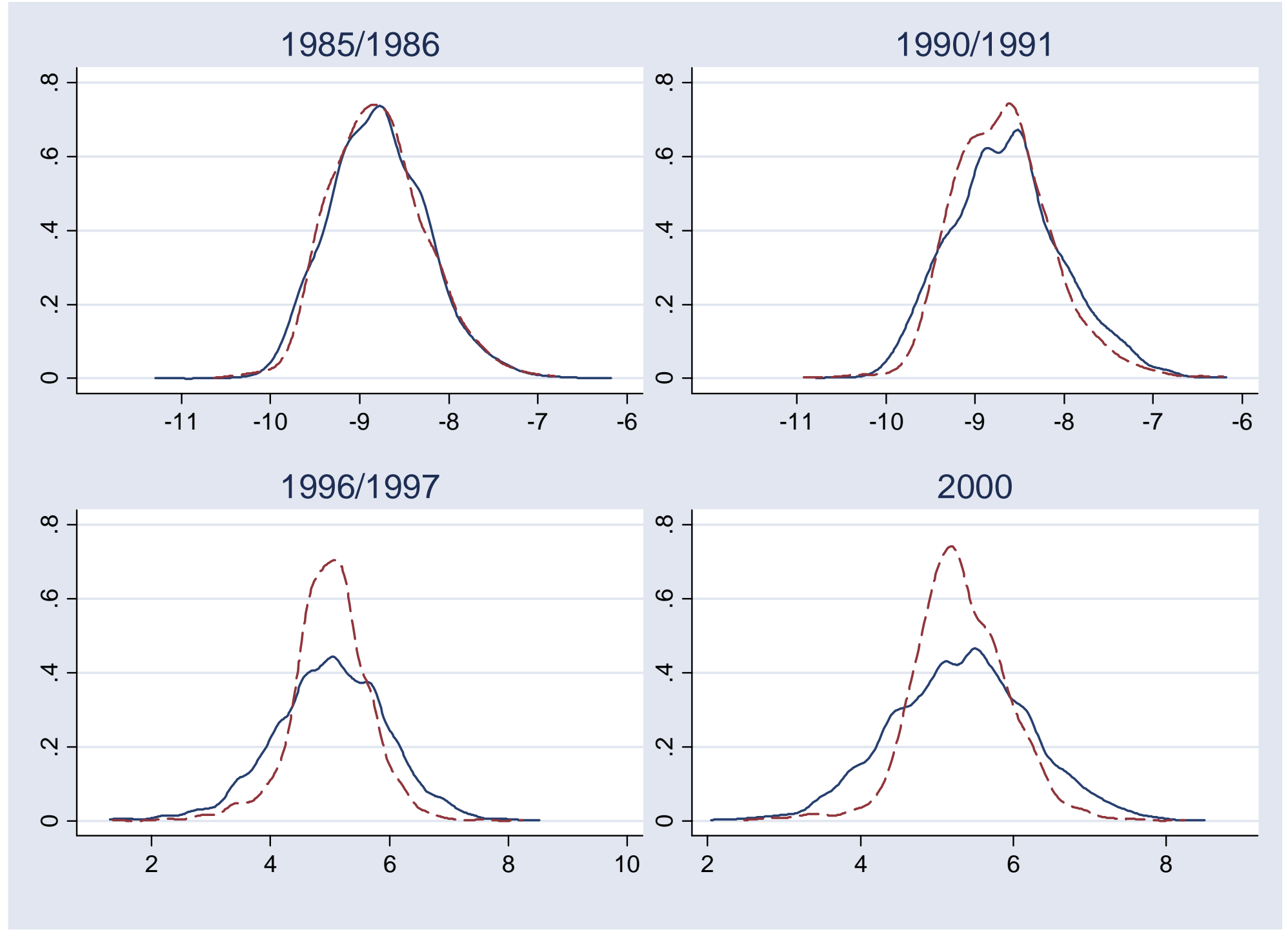

Note. In all graphs, broken and solid lines correspond to Ukraine and Russia, respectively. Wages are rescaled so that the mean log wages in Russia is equal to the mean log wage in Ukraine for each year. The plotted densities use Parzen kernel with bandwidth of 0.45. 
Figure 2: Distribution of the Returns to Schooling, Russia and Ukraine, Quantile Estimates
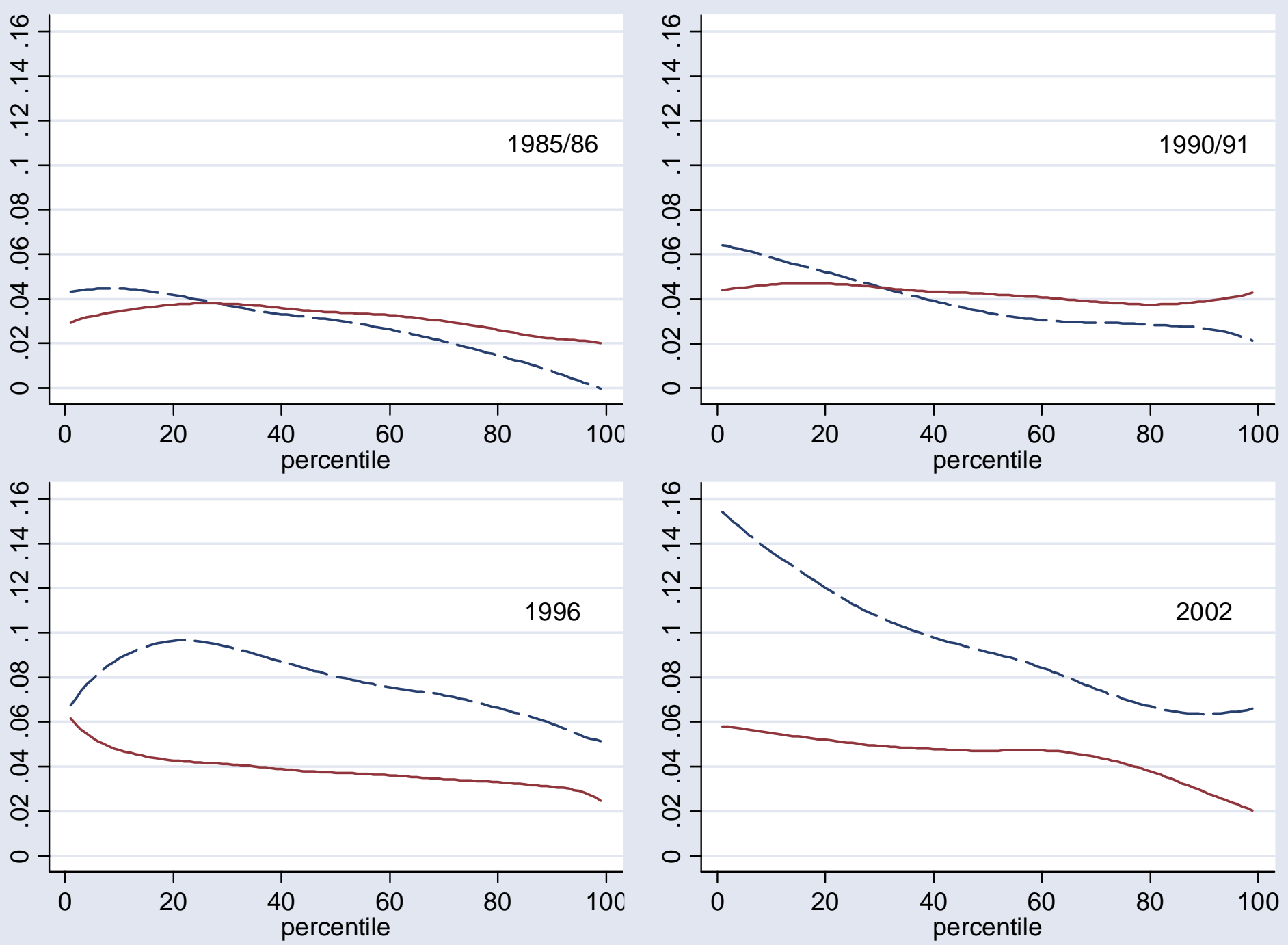

Note. In all graphs, broken and solid lines correspond to Ukraine and Russia, respectively. The estimated equation is the basic Mincerian specification shown in Table 2. A locally weighted regression (lowess) with bandwidth 0.5 is used to smooth percentile estimates in the figure. 
Figure 3: Kernel Density Estimates of Log Wages, Russia and Ukraine
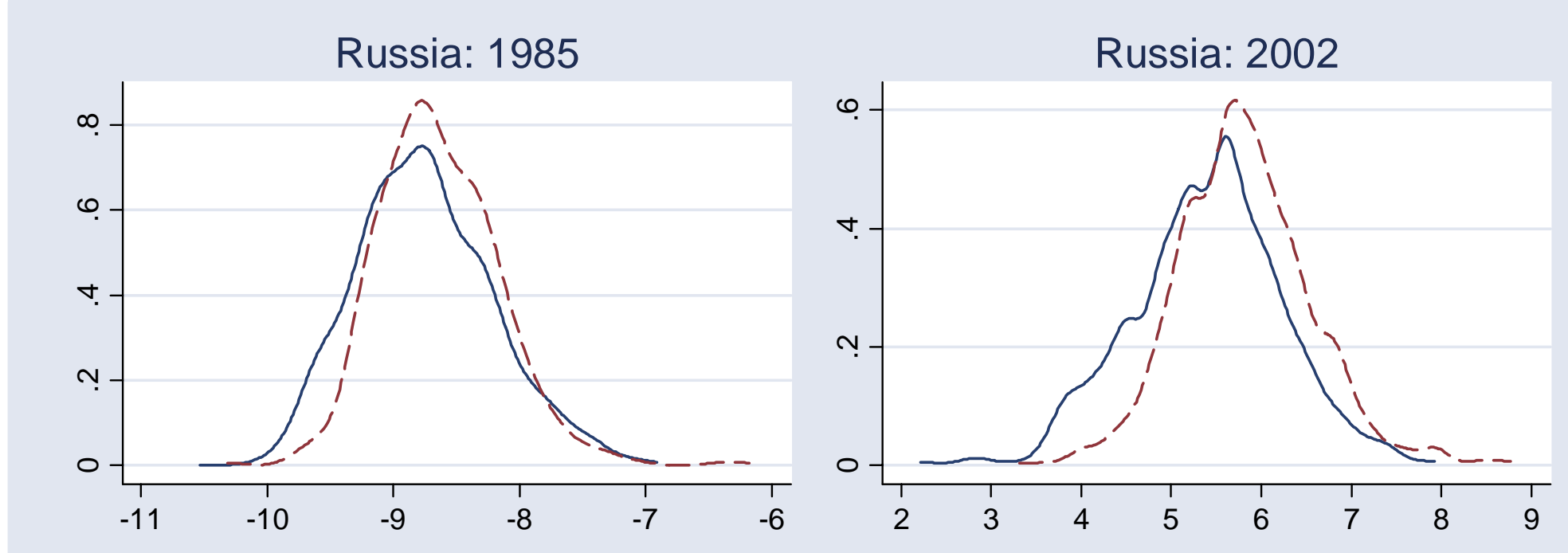

Ukraine: 1986
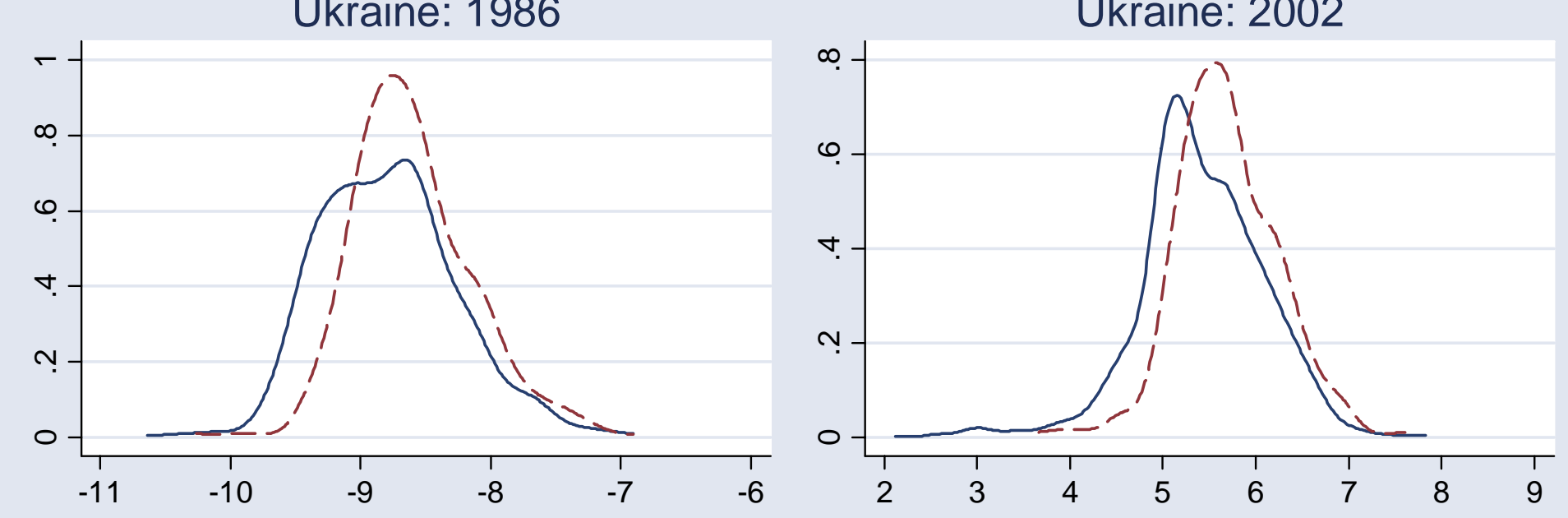

Note. In all graphs, broken and solid lines correspond to university and secondary school-educated workers, respectively. Wages are rescaled so that the mean log wages in Russia is equal to the mean log wage in Ukraine for each year. The plotted densities use Parzen kernel with bandwidth of 0.45 . 
Figure 4: Distribution of University Wage Premium, Russia and Ukraine

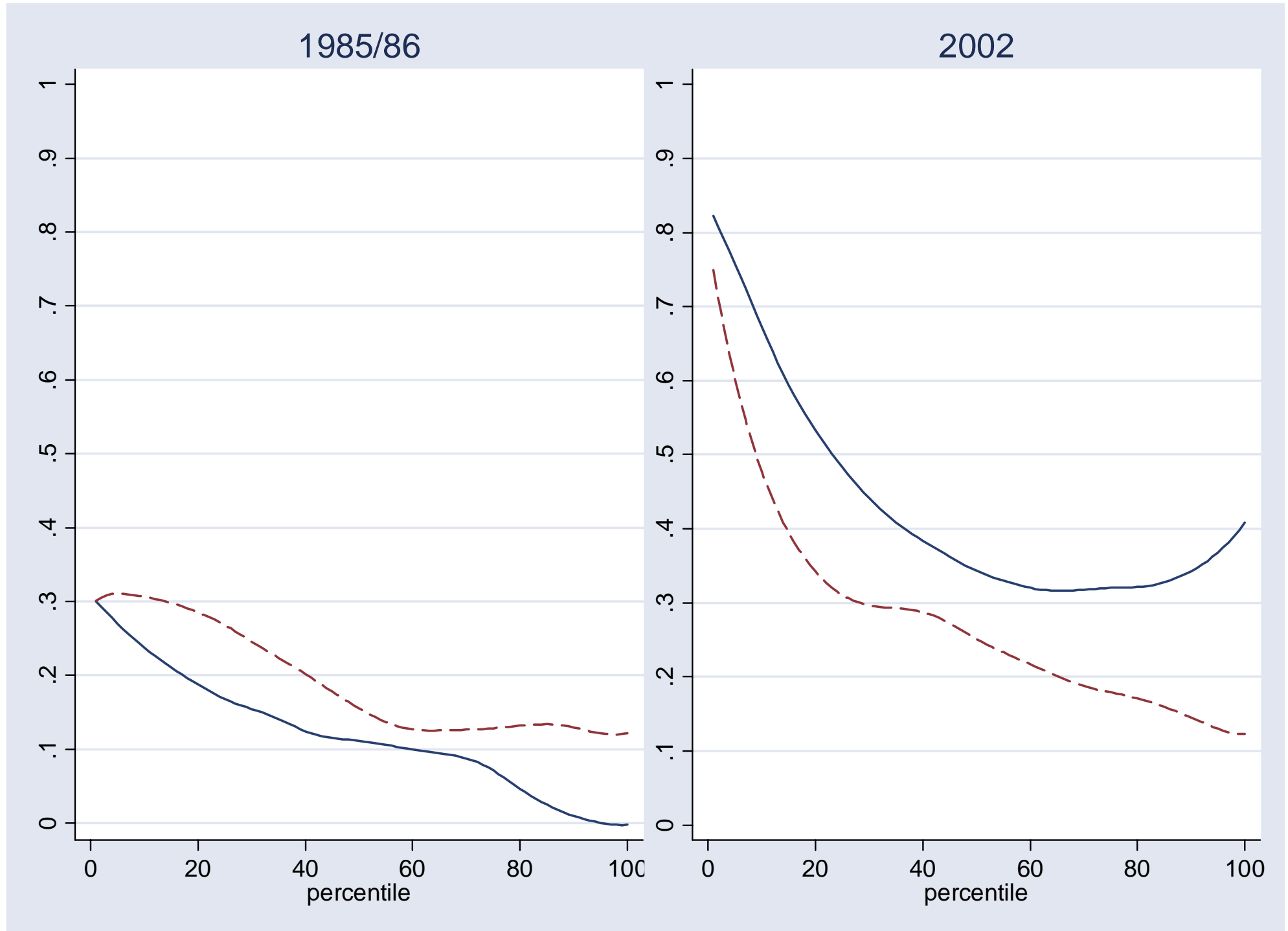

Note. In all graphs, broken and solid lines correspond to Ukraine and Russia, respectively. The university wage premium at a given percentile is defined as the differences in mean wages between university and secondary school-educated workers at a given percentile. A locally weighted regression (lowess) with bandwidth 0.5 is used to smooth percentile estimates in the figure. 
Figure 5: Actual and Counterfactual Distributions of University Wage Premium, 2002

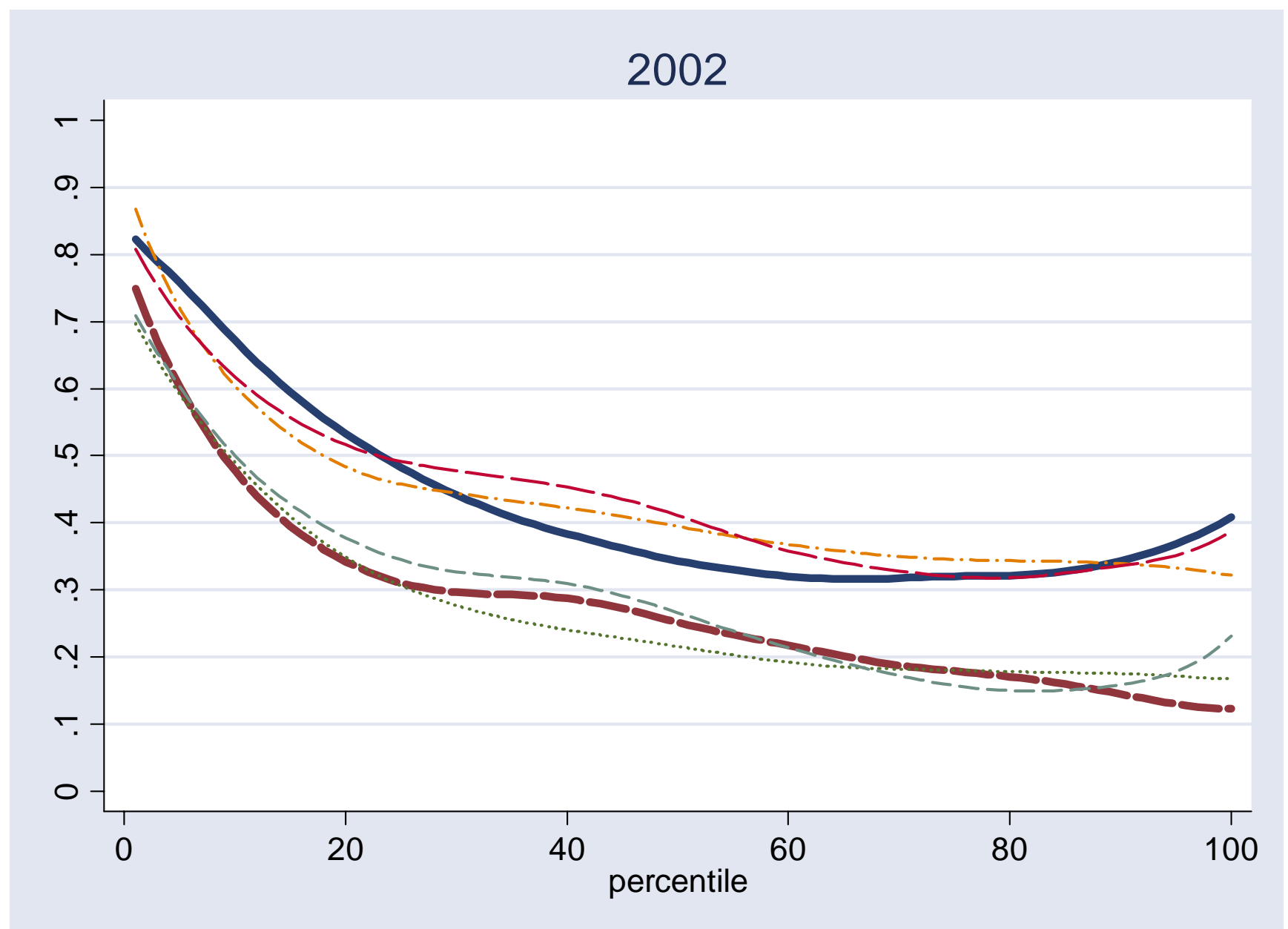

Note. The thick solid line is actual Russian distribution of university wage premium, the thick long dash line is actual Ukrainian distribution, the bottom dotted line is counterfactual 1 (Russian observables), the dash/dot line is counterfactual 2 (Russian prices), the dash line is counterfactual 3 (Russian unobservables), and the top long dash line is counterfactual 4 (Russian prices and unobservables). The university wage premium at a given percentile is defined as the differences in mean wages between university and secondary school-educated workers at a given percentile. A locally weighted regression ("lowess") with bandwidth 0.5 is used to smooth percentile estimates in the figure. 


\section{Appendix Table A1: Construction of the Sample}

Panel A. Russia

\begin{tabular}{lcccccc}
\hline & 1985 & 1990 & 1996 & 1998 & 2000 & 2002 \\
\hline Number of adult questionnaires & $\ldots$ & $\ldots$ & 8342 & 8701 & 9074 & 10497 \\
Representative cross-sections & 7074 & 7076 & 8122 & 7894 & 7568 & 7875 \\
Non-missing wages and schooling & 4230 & 3976 & 3684 & 3544 & 3384 & 3541 \\
Age 15-59 & 4121 & 3783 & 3501 & 3338 & 3176 & 3351 \\
Final sample & 4111 & 3776 & 3497 & 3332 & 3169 & 3341 \\
\hline \multicolumn{7}{l}{} \\
& \multicolumn{7}{l}{ Panel B. Ukraine } & & & & \\
\hline & 1986 & 1991 & 1997 & 1998 & 2000 & 2002 \\
\hline Non-missing wages and schooling & 4197 & 3577 & 3085 & 2958 & 3109 & 3504 \\
Age 15-59 & 4196 & 3541 & 2950 & 2819 & 2930 & 3291 \\
Final sample & 4191 & 3528 & 2946 & 2812 & 2925 & 3289 \\
\hline
\end{tabular}

Note. For 1996-2002, representative cross-sections in RLMS exclude respondents that moved from the original sample of dwellings to the new address. For 1985 and 1990, representative cross-sections show the number of respondents answered to the retrospective questions in 2000. The initial number of questionnaires in Ukraine was 8641. The final sample excludes a few outliers in log of wages. 


\section{Appendix Table A2: Definitions of Variables}

\begin{tabular}{|c|c|c|}
\hline Variable & Russia & Ukraine \\
\hline Wage & $\begin{array}{l}\text { - 1998-2002: Average monthly wage after } \\
\text { taxes at the primary job (regardless of } \\
\text { whether it was paid on time or not) for } \\
\text { employees; monetary and in-kind } \\
\text { payments actually received after taxes at } \\
\text { the primary job in the last } 30 \text { days for } \\
\text { self-employed; } \\
\text { - 1994-1996: We followed the method of } \\
\text { Earle and Sabirianova (2002), imputing } \\
\text { the contractual wage as the ratio of the } \\
\text { total wage debt to the number of monthly } \\
\text { wages owed; monetary and in-kind } \\
\text { payments actually received after taxes at } \\
\text { the primary job in the last } 30 \text { days for } \\
\text { employees without wage arrears and self- } \\
\text { employed } \\
\text { - 1985-1990: Average monthly wage }\end{array}$ & $\begin{array}{l}\text { Monthly contractual wage after taxes at the } \\
\text { primary job in December of the } \\
\text { corresponding year. All wages are } \\
\text { converted into hryvnyas. }\end{array}$ \\
\hline $\begin{array}{l}\text { Adjusted Years of } \\
\text { Schooling }\end{array}$ & $\begin{array}{l}\text { Education status from the survey has been } \\
\text { converted into a continuous variable } \\
\text { representing adjusted years of schooling. } \\
\text { To make them consistent with ULMS, } \\
\text { adjusted years of schooling were taken as } 4 \\
\text { for 1-6 grades, } 8 \text { for } 7-9 \text { grades, } 10 \text { for } 10- \\
12 \text { secondary school grades, } 9 \text { for a } \\
\text { vocational non-secondary school diploma, } \\
11.5 \text { for a vocational secondary school } \\
\text { diploma, } 13 \text { for a technical school diploma } \\
\text { and incomplete higher education, } 15 \text { for a } \\
\text { diploma of specialist, and } 18 \text { for a Ph.D. } \\
\text { degree. }\end{array}$ & $\begin{array}{l}\text { Education status from the survey has been } \\
\text { converted into a continuous variable } \\
\text { representing adjusted years of schooling. } \\
\text { Adjusted years of schooling were taken as } \\
4 \text { for 1- } 6 \text { grades, } 8 \text { for } 7-9 \text { grades, } 10 \text { for } \\
10-12 \text { secondary school grades, } 9 \text { for a } \\
\text { vocational non-secondary school diploma, } \\
11.5 \text { for a vocational secondary school } \\
\text { diploma, } 13 \text { for a technical school diploma } \\
\text { and incomplete higher education, } 14 \text { for a } \\
\text { bachelor degree, } 15 \text { for a diploma of } \\
\text { specialist, } 16 \text { for a master degree, and } 18 \\
\text { for a Ph.D. degree. Educational histories } \\
\text { are used to compute adjusted years of } \\
\text { schooling for previous years. Same } \\
\text { definitions are used to compute adjusted } \\
\text { years of schooling of parents. }\end{array}$ \\
\hline $\begin{array}{l}\text { Actual Years of } \\
\text { Schooling }\end{array}$ & $\begin{array}{l}\text { Total number of years in a school including } \\
\text { part-time schools, evening schools, and } \\
\text { courses by correspondence; available for } \\
\text { 1995-2002 }\end{array}$ & $\begin{array}{l}\text { Total number of years in a school including } \\
\text { part-time schools, evening schools, and } \\
\text { courses by correspondence; available for } \\
2002\end{array}$ \\
\hline Female & $=1$ if female & $=1$ if female \\
\hline $\begin{array}{l}\text { Potential Labor } \\
\text { Market Experience }\end{array}$ & Age minus years of schooling minus 6 & Age minus years of schooling minus 6 \\
\hline
\end{tabular}




\begin{tabular}{|c|c|c|}
\hline Tenure & $\begin{array}{l}\text { Number of years since an individual started } \\
\text { the primary job }\end{array}$ & $\begin{array}{l}\text { Number of years since an individual started } \\
\text { the primary job }\end{array}$ \\
\hline $\begin{array}{l}\text { Weekly Hours of } \\
\text { Work }\end{array}$ & $\begin{array}{l}\text { 2002: average hours in the usual work } \\
\text { week at the primary job }\end{array}$ & $\begin{array}{l}\text { 2002: hours per week an individual usually } \\
\text { works at the primary job; not available for } \\
\text { other years }\end{array}$ \\
\hline $\begin{array}{l}\text { Hours of Work } \\
\text { Missing }\end{array}$ & $=1$ if hours of work missing & $=1$ if hours of work missing \\
\hline University Degree & $=1$ if has completed higher education & $=1$ if has completed higher education \\
\hline Secondary School & $\begin{array}{l}=1 \text { if has completed secondary education } \\
\text { without secondary specialized or higher } \\
\text { education }\end{array}$ & $\begin{array}{l}=1 \text { if has completed secondary education } \\
\text { without secondary specialized or higher } \\
\text { education }\end{array}$ \\
\hline $\begin{array}{l}\text { Parents' } \\
\text { occupations }\end{array}$ & N/A & $\begin{array}{l}\text { Dummy variables for a manual non- } \\
\text { agricultural worker, a collective } \\
\text { farmer/agricultural worker, a non-manual } \\
\text { worker }\end{array}$ \\
\hline Capital & $=1$ if resides in Moscow & $=1$ if resides in Kyiv \\
\hline Foreign & $\begin{array}{l}=1 \text { if primary employer is owned or co- } \\
\text { owned by foreign firms or foreign } \\
\text { individuals }\end{array}$ & $\begin{array}{l}=1 \text { if primary employer is domestically } \\
\text { owned with some foreign capital or } \\
\text { foreign-owned (including international } \\
\text { organizations) }\end{array}$ \\
\hline Private & $\begin{array}{l}=1 \text { if primary employer is owned or co- } \\
\text { owned by Russian private firms or Russian } \\
\text { individuals (with no foreign participation); } \\
\text { or if an individual is self-employed }\end{array}$ & $\begin{array}{l}=1 \text { if primary employer is a privatized } \\
\text { enterprise, a newly established private } \\
\text { enterprise, or a cooperative (with no } \\
\text { foreign participation); or if an individual is } \\
\text { self-employed }\end{array}$ \\
\hline State & $=1$ if primary employer is owned by state & $\begin{array}{l}=1 \text { if primary employer is a budgetary } \\
\text { organization, a state enterprise, a local } \\
\text { municipal enterprise, a state farm, or a } \\
\text { collective farm }\end{array}$ \\
\hline Ownership Missing & $=1$ if ownership missing & $=1$ if ownership missing \\
\hline Firm Size & $\begin{array}{l}\text { Number of persons working at enterprise of } \\
\text { primary job: } 1-10,11-50,51-100,101-500 \text {, } \\
501-1000,1001+\text {, and no information; }=1- \\
10 \text { for self-employed. }\end{array}$ & $\begin{array}{l}\text { Number of persons working at enterprise } \\
\text { (workplace for self-employed) of primary } \\
\text { job: } 1-10,11-50,51-100,101-500,501- \\
1000,1001+\text {, and no information. }\end{array}$ \\
\hline
\end{tabular}




\section{Appendix Table A3: Employment Distribution by the Level of Schooling}

\begin{tabular}{lrrrrrr}
\multicolumn{7}{c}{ Panel A: Russia } \\
\multicolumn{1}{c}{ Schooling Level } & 1985 & 1990 & 1996 & 1998 & 2000 & 2002 \\
\hline Secondary school (0-6 grades) & 8.04 & 4.24 & 0.94 & 0.57 & 0.31 & 0.21 \\
Secondary school (7-9 grades) & 15.51 & 12.45 & 8.97 & 7.76 & 6.96 & 6.98 \\
Vocational school with no high school diploma & 5.66 & 5.35 & 4.06 & 4.31 & 3.94 & 3.43 \\
Secondary school (10-12 grades) & 23.32 & 24.19 & 24.51 & 23.67 & 23.68 & 23.31 \\
Vocational school with high school diploma & 10.68 & 13.67 & 15.08 & 16.48 & 18.23 & 17.52 \\
Technical school & 20.88 & 22.87 & 24.79 & 25.58 & 25.98 & 25.69 \\
University & 15.33 & 16.58 & 20.79 & 20.67 & 20.18 & 22.02 \\
Graduate school & 0.58 & 0.64 & 0.86 & 0.96 & 0.72 & 0.84 \\
\hline N Schooling Level & 4111 & 3776 & 3497 & 3332 & 3169 & 3341 \\
\hline & & & & & & \\
\hline \multicolumn{1}{c}{ Panel B: Ukraine } & & & & & \\
\hline Secondary school (0-6 grades) & 1986 & 1991 & 1997 & 1998 & 2000 & 2002 \\
\hline Secondary school (7-9 grades) & 6.56 & 2.95 & 1.02 & 0.67 & 0.61 & 0.46 \\
Vocational school with no high school diploma & 12.77 & 10.39 & 6.75 & 5.89 & 4.20 & 4.16 \\
Secondary school (10-12 grades) & 7.19 & 7.64 & 7.69 & 7.66 & 7.71 & 7.63 \\
Vocational school with high school diploma & 27.03 & 27.28 & 25.46 & 25.26 & 23.99 & 24.40 \\
Technical school & 11.62 & 14.56 & 15.12 & 16.03 & 17.41 & 17.44 \\
University & 21.56 & 22.54 & 26.17 & 26.36 & 26.76 & 25.71 \\
Graduate school & 12.83 & 14.23 & 17.69 & 18.02 & 19.11 & 20.02 \\
\hline N & 0.46 & 0.40 & 0.10 & 0.11 & 0.20 & 0.18 \\
\hline
\end{tabular}

Note. The sample is restricted to the respondents aged 15-59 with non-missing values for the variables used in the basic Mincerian wage function. The sample weights are applied for 1985/1986 and 1990/1991 in both countries. 


\section{DAVIDSON INSTITUTE WORKING PAPER SERIES - Most Recent Papers}

The entire Working Paper Series may be downloaded free of charge at: www.wdi.bus.umich.edu

CURRENT AS OF 9/24/2004

\begin{tabular}{|c|c|c|}
\hline Publication & Authors & Date \\
\hline $\begin{array}{l}\text { No. 720: An Analysis of Gender Wage Differentials in Russia from } \\
\text { 1996-2002 }\end{array}$ & Rita Hansberry & Sept. 2004 \\
\hline $\begin{array}{l}\text { No. 719: Returns to Schooling in Russia and Ukraine: } \\
\text { A Semiparametric Approach to Cross-Country Comparative Analysis }\end{array}$ & $\begin{array}{l}\text { Klara Sabirianova Peter and } \\
\text { Yuriy Gorodnichenko }\end{array}$ & Sept 2004 \\
\hline $\begin{array}{l}\text { No. 718: The emergence of large shareholders in mass privatized } \\
\text { firms: Evidence from Poland and the Czech Republic }\end{array}$ & Irena Grosfeld and Iraj Hashi & Aug. 2004 \\
\hline $\begin{array}{l}\text { No. 717: Wage Determination Under Communism and In Transition: } \\
\text { Evidence from Central Europe }\end{array}$ & $\begin{array}{l}\text { Swati Basu, Saul Estrin and Jan } \\
\text { Svejnar }\end{array}$ & Aug. 2004 \\
\hline No. 716: The Evolution of Cross-Region Price Distribution in Russia & Konstantin Gluschenko & July 2004 \\
\hline $\begin{array}{l}\text { No. 715: Languages in the European Union: The Quest for Equality and } \\
\text { its Cost }\end{array}$ & $\begin{array}{l}\text { Jan Fidrmuc and Victor } \\
\text { Ginsburgh }\end{array}$ & July 2004 \\
\hline $\begin{array}{l}\text { No. 714: Voice of the Diaspora: An Analysis of Migrant Voting } \\
\text { Behavior }\end{array}$ & Jan Fidrmuc and Orla Doyle & July 2004 \\
\hline $\begin{array}{l}\text { No. 713: International Coercion, Emulation and Policy Diffusion: } \\
\text { Market-Oriented Infrastructure Reforms, 1977-1999 }\end{array}$ & $\begin{array}{l}\text { Witold J. Henisz and Bennet A. } \\
\text { Zelner and Mauro F. Guillen }\end{array}$ & July 2004 \\
\hline $\begin{array}{l}\text { No. 712: Votes and Vetoes: The Political Determinants of Commercial } \\
\text { Openness }\end{array}$ & $\begin{array}{l}\text { Witold J. Henisz and Edward D. } \\
\text { Mansfield }\end{array}$ & July 2004 \\
\hline $\begin{array}{l}\text { No. 711: Interest Groups, Veto Points and Electricity Infrastructure } \\
\text { Deployment }\end{array}$ & $\begin{array}{l}\text { Witold J. Henisz and Bennet A. } \\
\text { Zelner }\end{array}$ & July 2004 \\
\hline $\begin{array}{l}\text { No. 710: Firms' Price Markups and Returns to Scale in Imperfect } \\
\text { Markets: Bulgaria and Hungary }\end{array}$ & $\begin{array}{l}\text { Rumen Dobrinsky, Gábor Körösi, } \\
\text { Nikolay Markov, and László } \\
\text { Halpern }\end{array}$ & July 2004 \\
\hline $\begin{array}{l}\text { No. 709: The Stability and Growth Pact from the Perspective } \\
\text { of the New Member States }\end{array}$ & Gábor Orbán and György Szapáry & July 2004 \\
\hline $\begin{array}{l}\text { No. 708: Contract Violations, Neighborhood Effects, and Wage Arrears } \\
\text { in Russia }\end{array}$ & Klara & July 2004 \\
\hline $\begin{array}{l}\text { No. 707: Determinants of Employment Growth at MNEs: Evidence } \\
\text { from Egypt, India, South Africa and Vietnam }\end{array}$ & $\begin{array}{l}\text { haumik, Saul } \\
\text { Meyer }\end{array}$ & July 2004 \\
\hline $\begin{array}{l}\text { No. 706: Economic Reform in Tanzania and Vietnam: A Comparative } \\
\text { Commentary }\end{array}$ & $\begin{array}{l}\text { Brian Van Arkadie and Do Duc } \\
\text { Dinh }\end{array}$ & June 2004 \\
\hline $\begin{array}{l}\text { No. 705: Beliefs about Exchange-Rate Stability: Survey Evidence } \\
\text { from the Currency Board in Bulgaria }\end{array}$ & $\begin{array}{l}\text { Neven T. Valev and John A. } \\
\text { Carlson }\end{array}$ & June 2004 \\
\hline No. 704: Returns to Schooling in China Under Planning and Reform & $\begin{array}{l}\text { Belton M. Fleisher and Xiaojun } \\
\text { Wang }\end{array}$ & June 2004 \\
\hline $\begin{array}{l}\text { No. 703: Return to Skills and the Speed of Reforms: Evidence from } \\
\text { Central and Eastern Europe, China and Russia }\end{array}$ & $\begin{array}{l}\text { Belton M. Fleisher, Klara } \\
\text { Sabirianova Peter, and Xiaojun } \\
\text { Wang }\end{array}$ & June 2004 \\
\hline $\begin{array}{l}\text { No. 702: What Makes Small Firms Grow? Finance, Human C } \\
\text { Technical Assistance, and the Business Environment in Rome }\end{array}$ & $\begin{array}{l}\text { J. David Brown, John S. Earle } \\
\text { and Dana Lup }\end{array}$ & May 2004 \\
\hline $\begin{array}{l}\text { No. 701: The Effects of Multiple Minimum Wages Throughout the } \\
\text { Labor Market }\end{array}$ & $\begin{array}{l}\text { T. H. Gindling and Katherine } \\
\text { Terrell }\end{array}$ & May 2004 \\
\hline No. 700: Minimum Wages, Inequality and Globalization & $\begin{array}{l}\text { T. H. Gindling and Katherine } \\
\text { Terrell }\end{array}$ & May 2004 \\
\hline No. 699: Self-Selection and Earnings During Volatile Transition & Ralitza Dimova and Ira Gang & May 2004 \\
\hline No. 698: Ecology and Violence: The Environmental Dimensions of War & $\begin{array}{l}\text { Timothy L. Fort and Cindy A. } \\
\text { Schipani }\end{array}$ & May 2004 \\
\hline $\begin{array}{l}\text { No. 697: Russian Cities in Transition: The Impact of Market Forces in } \\
\text { the 1990s }\end{array}$ & Ira N. Gang and Robert C. Stuart & May 2004 \\
\hline $\begin{array}{l}\text { No. 696: Firm Ownership and Internal Labor Practices in a Transition } \\
\text { Economy: An Exploration of Worker Skill Acquisition in Vietnam }\end{array}$ & Jed Friedman & May 2004 \\
\hline No. 695: The Unanticipated Effects of Insider Trading Regulation & $\begin{array}{l}\text { Art A. Durnev and Amrita S. } \\
\text { Nain }\end{array}$ & May 2004 \\
\hline
\end{tabular}

